San Jose State University

SJSU ScholarWorks

Master's Theses

Master's Theses and Graduate Research

Summer 2013

\title{
Use of DNA Sequences to Identify Forensically Important Fly Species in the Coastal Region of Central California (Santa Clara County)
}

Angela T. Nakano

San Jose State University

Follow this and additional works at: https://scholarworks.sjsu.edu/etd_theses

\section{Recommended Citation}

Nakano, Angela T., "Use of DNA Sequences to Identify Forensically Important Fly Species in the Coastal Region of Central California (Santa Clara County)" (2013). Master's Theses. 4357.

DOI: https://doi.org/10.31979/etd.8rxw-2hhh

https://scholarworks.sjsu.edu/etd_theses/4357

This Thesis is brought to you for free and open access by the Master's Theses and Graduate Research at SJSU ScholarWorks. It has been accepted for inclusion in Master's Theses by an authorized administrator of SJSU ScholarWorks. For more information, please contact scholarworks@sjsu.edu. 


\title{
USE OF DNA SEQUENCES TO IDENTIFY FORENSICALLY IMPORTANT FLY SPECIES IN THE COASTAL REGION OF CENTRAL CALIFORNIA (SANTA CLARA COUNTY)
}

\author{
A Thesis \\ Presented to \\ The Faculty of the Department of Biological Sciences \\ San José State University \\ In Partial Fulfillment \\ of the Requirements for the Degree \\ Master of Science
}

by

Angela T. Nakano

August 2013 
(C)2013

Angela T. Nakano

ALL RIGHTS RESERVED 
The Designated Thesis Committee Approves the Thesis Titled

\title{
USE OF DNA SEQUENCES TO IDENTIFY FORENSICALLY IMPORTANT FLY SPECIES IN THE COASTAL REGION OF CENTRAL CALIFORNIA (SANTA CLARA COUNTY)
}

\author{
by \\ Angela T. Nakano \\ APPROVED FOR THE DEPARTMENT OF BIOLOGICAL SCIENCES \\ SAN JOSÉ STATE UNIVERSITY
}

August 2013

Dr. Jeffrey Honda Department of Biological Sciences

Dr. Scott Shaffer Department of Biological Sciences

Dr. Noor Tietze Santa Clara County Vector Control District 


\section{ABSTRACT \\ USE OF DNA SEQUENCES TO IDENTIFY FORENSICALLY IMPORTANT FLY SPECIES IN THE COASTAL REGION OF CENTRAL CALIFORNIA (SANTA CLARA COUNTY)}

by Angela T. Nakano

Forensic entomology has gained prominence in recent years, as improvements in DNA technology and molecular methods have allowed insect and other arthropod evidence to become increasingly useful in criminal and civil investigations. However, comprehensive faunal inventories are still needed, including cataloguing local DNA sequences for forensically significant Diptera. This multi-year fly-trapping study was built upon and expanded a previous survey of these flies in Santa Clara County, including the addition of genetic barcoding data from collected species of flies.

Flies from the families Calliphoridae, Sarcophagidae, and Muscidae were trapped in meat-baited traps set in a variety of locations throughout the county. Flies were identified using morphological features and confirmed by molecular analysis. A total of 16 calliphorid species, 14 sarcophagid species, and four muscid species were collected and differentiated. This study found more species of flies than previous area surveys and established new county records for two calliphorid species: Cynomya cadaverina and Chrysomya rufifacies. Significant differences were found in fly fauna in different areas of the county $(\mathrm{p}<0.025)$, indicating the importance of microclimates in the distribution of these flies. Molecular analysis supported the use of DNA barcoding as an effective method of identifying cryptic fly species. 


\section{ACKNOWLEDGEMENTS}

My sincere thanks to Dr. Jeffrey Honda for sharing with me his patience, expertise, enthusiasm and passion for entomology. Without Jeff, none of this would have come together at all.

Another big thank you goes to Dr. Noor Tietze and Dr. Scott Shaffer for reviewing my thesis and providing helpful editorial feedback and general advice. It was very much appreciated!

I also need to credit my student assistants for their invaluable contributions in the field and the lab: Karla Abea, Cecilia Santos, and Brindha Kumar, you ladies are the best.

To my family and friends who have asked me if I was done with my thesis about a hundred million times, thanks for keeping me honest. I know that each time you asked me about it, what you really meant was, "You're almost awesome." And now I am.

And finally, to my beloved Courtney, thanks for sticking by me. I can't wait to see what life is like when it's finally just you and me and no thesis. 


\section{TABLE OF CONTENTS}

List of Tables........................................................ vii

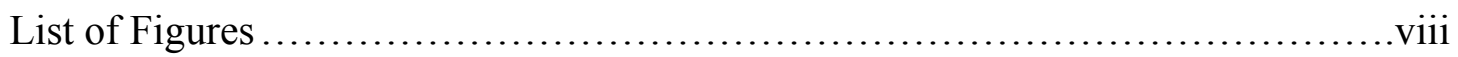

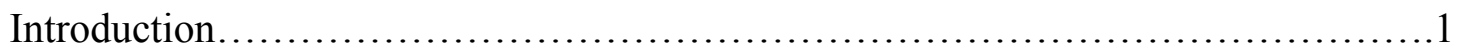

Materials and Methods....................................................... 12

Results .............................................................. 21

Discussion.......................................................... 46

Conclusion............................................................. 56

Literature Cited ............................................................. 57 


\section{LIST OF TABLES}

Table 1. Calliphorids in Santa Clara, San Mateo, Alameda, and Santa Cruz Counties, as recorded in previous publications

Table 2. Descriptions of standardized fly trapping sites

Table 3. Species checklist of forensically significant calliphorid flies recorded in previous and current studies (adapted in part from Brundage et al. (2011))

Table 4. Genetic distances (K2P percentage divergences) between calliphorids sequenced in the current study and sequences obtained from GenBank

Table 5. Counts of trapping events resulting in captures of four calliphorid species in the east and west sides of Santa Clara County

Table 6. Genetic distances (K2P percentage divergences) between Sarcophagids sequenced in the current study and sequences Obtained from GenBank

Table 7. Genetic distances (K2P percentage divergences) between sarcophagids identified as Sarcophaga bullata sequenced in the current study (CS), selected sequences obtained from GenBank (GB), and a representative sarcophagid identified as Liosarcophaga sarracenioides from the current study.

Table 8. Bait associated with sarcophagid collections in the current study

Table 9. Genetic distances (K2P percentage divergences) between muscids sequenced in the current study and sequences obtained from GenBank

Table 10. Comparison of calliphorid collection methods and results From Santa Clara County used in the current study and in Brundage et al. (2011) 


\section{LIST OF FIGURES}

Figure 1. Location of fly traps set regularly from July 2010 through June 2011

Figure 2. Comparison of Lucilia sericata and Lucilia thatuna.

Figure 3. Trap seasonality of selected calliphorid species

Figure 4. Distribution of selected calliphorid species

Figure 5. Captures of selected calliphorid species by bait type

Figure 6. Location of new county records for species Chrysomya rufifacies and Cynomya cadaverina

Figure 7. Seasonal distribution of collections of forensically significant species of sarcophagid flies found in this study (July 2010 - June 2011)

Figure 8. Collection locations of forensically significant species of sarcophagid flies in this study

Figure 9. Seasonal distribution of collections for some of the species of sarcophagid flies of negligible or questionable forensic significance found in this study

Figure 10. Locational distribution of trap results for some of the species of sarcophagid flies of negligible or questionable forensic significance found in this study

Figure 11. Seasonal distribution of trap results for some of the species of muscid flies trapped in this study that had previously been assumed to be uncommon in this area.

Figure 12. Trap location breakdown for some of the species of muscid flies trapped in this study that had previously been assumed to be uncommon in this area 


\section{Introduction}

Accurate species identification and up-to-date locality information are essential for the effective application of forensic entomology in criminal investigations. Recent research has shown DNA barcoding to be one of the fastest and most reliable methods of accomplishing species-level identification $[1,2]$. However, some limitations of molecular identification methods include the need for comprehensive local fauna inventories, including cataloguing local DNA sequences for the Diptera, including the Calliphoridae, Muscidae, and Sarcophagidae. With the exception of a survey of forensic flies based solely on morphological identification conducted from 2001 to 2003 [3], comprehensive and confirmable species records for calliphorid flies found in the California coastal region are incomplete, and virtually nonexistent for muscid and sarcophagid flies, with the exception of an unpublished survey of museum specimens included in a recent master's thesis [4]. A comprehensive local DNA catalogue for forensic fly families has yet to be compiled [5]. This study seeks to address both issues as well as to assess whether molecular identification methods provide efficient and reliable results for this application.

\subsection{Forensic Entomology}

Forensic entomology is broadly defined as the application of insect or arthropod studies for use in legal proceedings [6]. Though this may technically include cases ranging from lawsuits involving insects in canned foods or bedbug infestations in hotels, the most well publicized function of arthropod evidence is related to criminal actions and homicide cases. Because of the various incarnations of television shows such as C.S.I., 
this "medicolegal" or "medicocriminal" function now encompasses the entirety of what most people now consider forensic entomology, and it is in this context that we have used the term herein.

The field of forensic entomology has progressed over the centuries to become highly specialized. Comprehensive reviews of forensic applications of insects by Catts and Goff [7] and Keh [8] both cite a Chinese textbook from 1235 AD as the earliest known documentation of insect use as evidence. In The Washing Away of Wrongs, lawyer Sung Tzu described how flies were attracted to invisible blood remnants on a sickle used as a murder weapon, thus implicating a suspect [9]. While art depicting worms or maggot-ridden corpses can be found scattered throughout the $15^{\text {th }}$ and $16^{\text {th }}$ centuries, the first modern forensic entomology case report did not appear until 1855, when French doctor Bergeret used flies and moths present on a body to estimate the length of time that had elapsed since a person had died [10]. This was later termed the postmortem interval (PMI). Bergeret applied a rudimentary form of what would later be known as insect succession, namely that different types of insects and arthropods tended to infest dead bodies at different periods of decomposition. Because flies generally invaded corpses immediately and certain types of moths would lay eggs only on bodies that had already dried out, he concluded that the presence of pupal casings from both insects meant that the body had lain in its current location for a long period of time. French researcher Paul Brouardel, who studied Bergeret's work, used arthropod biology and succession information to determine that an infant found as a mite-infested corpse probably died over six months before it was found ([11] as cited in [12]). 
The end of the $19^{\text {th }}$ century saw the first real push to advance scholarly work on insect and arthropod succession. A few researchers in Europe published studies on the discrete stages of corpse decomposition and attendant insects and mites [12], including German doctor Hermann Reinhard [13], Austrian physician O. Hofmann [14], and French researcher M. Georges Yovanovich [15]. Most significantly, French doctor Jean Pierre Mégnin [16] developed a table of eight standard stages of decomposition with the predictable arthropod fauna associated with each stage [8]. Mégnin's published books and forensic entomology case studies raised the profile of the discipline, inspiring a burst of research into succession studies. In 1895, Wyatt Johnston and Geoffrey Villeneuve in Canada [17] and Murray Galt Motter [18] in Washington, D.C., launched separate studies which would refine and, in some cases, challenge Mégnin's theories [12].

Over the next century, forensic entomology continued to develop along two parallel, but complementary, paths of study: fauna on corpses and temperature-related effects. An increase in general zoological and ecological studies provided examinations of a number of saprophagous insects. In turn, this enhanced understanding of insect life histories led to a dramatic improvement in the value of flies and their maggots to estimate post mortem interval. In addition to using succession information to tell how long after death a particular type of insect was likely to be found on a body, entomologists could also apply knowledge about the temperature-dependent development times of specific fly and other arthropod species to estimate how long an insect specimen in a particular life stage had been present. The approximate time of death could then be calculated with much greater precision. 
Criminal investigators gradually expanded the boundaries of forensic entomology over the years with a diverse set of case studies. Maschka [19], Klingelhoffer [20], and Horoszkiewicz [21] published separate cases of parents being exonerated from child abuse cases when the wounds on the deceased child were proved to have been caused by cockroaches, ants, and other invertebrates. In his 1998 paper [22], Benecke listed a number of ways, aside from establishing PMI, in which crime scene insects had been used in published case files, including linking suspects to a crime scene by their insect bites [23, 24], region-specific insect evidence proving bodies have been moved, and filth fly larvae proving an extended duration of child neglect [25].

\subsection{Forensic Entomology Today}

Modern-day medicocriminal entomologists still employ both succession and development data to estimate post-mortem interval. All methods require reliable background entomology research, skilled collection techniques, and reliable identification of insect specimens. Correct fly identification has become especially critical in recent years, as an ever-growing array of dipteran species are being utilized in forensic entomology. A cursory search of recent literature locates a number of fly families containing species that have been used to estimate PMI, including Muscidae, Calliphoridae, Sarcophagidae, Stratiomyiidae, and Phoridae [26-29]. Some of the more novel forensic flies, such as the black soldier fly Hermetia illucens, are easily recognizable. However, many of the fly species frequently used to estimate PMI can be extremely difficult to tell apart using only morphological features [5]. 
To overcome these challenges, forensic entomologists have turned to DNA sequencing technologies. Before molecular techniques were available, the larval or pupal stages of blow flies usually found at crime scenes would often have to be successfully reared to the adult stage in the lab in order to obtain a positive identification [30]. This can prove impossible when only a small number of samples are collected, or specimens are dead or in poor condition. Molecular techniques now allow forensic entomologists to obtain a molecular identification directly from the larval or pupal stages, even when the specimen is in sub-optimal condition or does not survive to the adult stage [27]. Enough DNA for sequencing can be extracted readily from a small amount of insect tissue, and usable DNA can be obtained even from empty puparia [31].

Mitochondrial DNA (mtDNA) sequences, especially those from the cytochrome oxidase I (COI) gene, are currently favored for distinguishing invertebrate species. In addition to being resistant to degradation, mitochondrial genes were found to have high enough mutation rates to reveal species-level distinctions by sequencing even short $(<300$ bp) regions $[31,32]$. This feature of mitochondrial DNA makes it particularly attractive for forensic applications, where specimens are often incomplete or aged [33]. By contrast, a fly study sequencing RNA from ribosomes (rRNA) found that the entire $28 \mathrm{~S}$ (large) subunit rRNA sequence ( $2148 \mathrm{bp}$ ) had to be sequenced in order to distinguish different species of calliphorids [34]. Because mitochondrial genes are involved with oxidative respiration, Sperling et al. [32] also suggests that relationships in mtDNA lineages may assist in extrapolating development times for forensic fly species that do not currently have established degree-day models. 
To test how COI identification performs specifically for calliphorids, the flies most often used to estimate PMI, a 304 bp sequence of the COI gene was compared from 291 specimens ( 245 new specimens and 51 from published literature) in a study by J. Wells and D. Williams [35]. While statistical analysis showed that correct identifications were strongly supported, some closely related species could not be distinguished by this technique. Wells and Williams emphasized the importance of considering non-genetic information, such as natural history, seasonality, or geographic distribution, when using molecular techniques for identification. When limited to a well-described geographic region, $\mathrm{COI}$ sequences were found to be a reliable way to distinguish these fly species for forensic purposes [35].

A large body of molecular data has been amassed in recent years, as the need for a comprehensive set of reference DNA for forensic flies increases [36]. Forensic entomologists and other researchers can compare sequences of their evidence item to reference sequences in a databank of published DNA sequences such as GenBank. Dawnay, Ogden, McEwing, Carvalho, and Thorpe [37] tested the effectiveness of checking experimentally sequenced DNA against data in GenBank for use in forensic applications, finding that though the essential methodology and concept behind the model were sound, the value in real-life situations was limited by the integrity and completeness of the reference DNA sequence collection. One troubling example involved a human DNA sample which produced a 100\% match with five invertebrate species in GenBank, implying that compromised sequences existed in the reference collection, likely due to contamination that occurred during the original sequence submissions [37]. Park et al. 
[38] cites a fly from China identified as Aldrichina grahami in GenBank, whose DNA sequence diverged significantly (6.5-6.9\% sequence distances) from both their own sequences from the same species in Korea and other sequences of $A$. grahami within GenBank. The authors found this fly matched up closely $(0.7-1.4 \%$ sequence distance) to their Calliphora vicina samples, suggesting the Chinese fly in GenBank had most likely been misidentified. While the need for more banked sequences is imperative, more rigorous standards for sequence submission may be essential in the future to preserve data integrity.

As the body of GenBank data grows, so may the temptation to simply rely on published material when it becomes available rather than proactively conduct regional surveys to collect and submit sequences from local fly specimens. Stevens and Wall [34] and Wells and William [35] both stress the need for more original data from localities worldwide, both to refine identifications down to the subspecies level and to account for variations in different geographic regions. In a study using COI to identify calliphorids in the genus Lucilia, Wells, Wall, and Stevens [39] found that whereas L. cuprina and $L$. sericata have distinct COI haplotypes in most parts of the world, they were not able to definitively distinguish samples in Taiwan using this gene. They also noted that while $L$. illustrus and L. caesar have very similar COI patterns, the fact that only L. illustrus is known to occur in the New World significantly improves the utility of the molecular data. Geographic distribution information is a key component that critically augments molecular techniques for identification of calliphorid species. 
In the San Francisco Bay Area, local DNA reference data for calliphorids are scarce and is almost nonexistent for forensic sarcophagid species [5]. Although a number of comprehensive publications exist on calliphorids, most are broad identification keys or textbooks that indicate specific locality information down to the state level [40, 41]. Only two publications to date have made any attempt to catalogue calliphorid species of forensic concern in California. The most comprehensive California fly distribution information is found in James [42], from museum-collected specimens. A San José State University study of calliphorid flies trapped in Santa Clara County, California [43] offered a more recent assemblage of the regional calliphorid fauna and added a new record for Lucilia mexicana, but failed to find a number of species that had previously been recorded in the county. As shown in Table 1, Brundage et al. [43] found only seven of the fifteen forensically significant calliphorids with well described records in Santa Clara and surrounding counties (Alameda, San Mateo, and Santa Cruz) cited in James [42]. 
Table 1

Calliphorids in Santa Clara, San Mateo, Alameda, and Santa Cruz Counties, as recorded in previous publications

\begin{tabular}{|ll|}
\hline James [42] & Brundage et al. [43] \\
\hline $\begin{array}{l}\text { Calliphora coloradensis } \\
\text { Calliphora grahami } \\
\text { Calliphora latifrons } \\
\text { Calliphora livida } \\
\text { Calliphora terraenovae } \\
\text { Calliphora vicina } \\
\text { Calliphora vomitoria }\end{array}$ & \\
Cochliomyia macellaria & Calliphora latifrons \\
Compsomyiops callipes & Calliphora vomitoria \\
$\begin{array}{l}\text { Lucilia cuprina } \\
\text { Lucilia elongata }\end{array}$ & \\
Lucilia sericata & Compsomyiops callipes \\
Lucilia silvarum & Lucilia cuprina \\
Lucilia thatuna & Lucilia mexicana \\
Phormia regina & Lucilia sericata \\
\hline
\end{tabular}

${ }^{a}$ Names used for flies are as delineated in Whitworth [41]. Several genera and species names have undergone revision since James [42].

It was unclear if the collection methods in Brundage et al. [43] selected for detection of only a subset of currently present calliphorid flies, or whether the diversity of local flies had actually reduced dramatically since 1955 . Recent evidence indicates the first explanation. Brundage et al. [43] notes that the sole use of beef liver as bait may have excluded many of the available calliphorid species from traps. Fly trapping in the same region with different types of meat baits by students in a recent class at San José State University captured a number of blow fly species present in the area that were not 
found in Brundage et al. [43], suggesting increasing bait variety may lead to a greater diversity of flies collected [5]. Personal experience has also revealed that some flies seem to be "trap shy," in that flies of some species have been observed hovering near baited traps that were not the same as the fly species found inside those same traps. Sweep netting in the vicinity of the traps can allow sampling of those species that do not go into meat traps even when attracted to the bait.

Another possible explanation for the absence of some flies from Brundage et al. [43] is the limited identification methods used in the study. Identification of flies using physical characteristics is difficult under ideal circumstances, and relies upon expert knowledge of the placement and abundance of hairs and bristles, gradations of pigmentation, and other subtle, microscopic features. Brundage et al. [43] notes that although over 34,000 flies were identified using physical features, trapping methods used in the study damaged several thousand of collected flies past the point of identification. Combining molecular techniques with traditional morphological identification methods could have allowed for the identification of more severely damaged specimens, as well as bring an added measure of confidence to the determinations of identified specimens.

An even more egregious deficiency in forensic entomological data is the lack of any collection information for local sarcophagids and muscids in the published literature. Sarcophagids are underutilized in PMI estimations because of the difficulties in identification and the lack of distributional and thermobiological data [44]. The same issues exist for saprophagous species of muscids. Forensic entomology can only be 
exercised effectively when the local surveys have laid the groundwork for accurate and specific results $[6,43]$. As the use of forensic entomology grows in frequency and scope, the demand for solid local data on families of flies other than calliphorids will correspondingly increase.

In this study, I trapped forensically significant flies over a number of seasons in Santa Clara County using a variety of bait types. I demonstrate that diversified collection and identification methods can dramatically expand the local catalogue of forensic flies. This project bridges the gap between historical fly records and more recent research with new approaches to fly collection as well as evaluates and confirms the utility of DNA sequencing for quick and reliable identification of the more cryptic species. I do not revisit the natural history or distribution of local species of record as they have been previously described in other studies. However, I do note new records of flies collected in the area and record repeated occurrences of calliphorid, sarcophagid, and muscid flies for which the continued local presence had been under question in the literature. 


\section{Materials and Methods}

\subsection{Pilot Studies 2005-2009}

During this five-year period, we utilized a number of traps and collecting methods to capture flies in both urban and rural areas of Santa Clara, Santa Cruz, and San Mateo Counties. Flies were collected using a combination of methods, including homemade soda bottle traps as constructed per Honda [5], sweep-netting, and one instance of a slightly modified CDC Gravid Trap Model 1712 (John W. Hock Company, Gainesville, FL) deployed for a week over a cardboard box containing a crow carcass. Store-bought insect traps of the type used previously by Brundage et al. [43] were field-tested but did not perform as well as the the homemade bottle traps.

Although the goal was to capture the greatest number of fly species that could be of value in criminal investigations, for obvious reasons human cadavers were not available as bait. The previous local fly survey relied solely upon beef liver mixed with water [43]. The literature provides a wide assemblage of bait examples, from pork liver and raw squid [38] to whole rabbit carcasses $[45,46]$. For this project, several different bait types were tested, including fish and cuts of chicken, turkey, pork and beef in varying stages of freshness, spoilage, and decay. While not quantified, it was determined that the homemade bottle traps baited with rancid fish captured a relatively high volume and diversity of flies over a $24-\mathrm{h}$ period.

In conjunction with the trapping efforts, from 2005-2007, 2-4 bottle traps were set per week at urban and rural sites primarily during the summer, when the largest 
assortment of calliphorid species have been collected [3] and weather conditions were the most agreeable. Trapping was conducted on a sporadic basis in spring, fall, and winter in an attempt to collect the remaining species of record.

The combination of these trapping efforts, supplemented by opportunistic handcollecting of observed specimens, was successful for completing the collection of most of the historically recorded species of calliphorids in the region. Moreover, some of the traps placed in two rural areas (Grant Lake and Skyline) captured a number of flies not previously collected in the area by Brundage et al. [43]. A number of unidentified sarcophagids and muscids were collected from these traps. Standardized trapping sites are listed in Table 2 and pictured in Figure 2. A small number of flies that were trapped or swept from single-occurrence collection sites in Santa Clara or San Mateo County were also included in portions of this study.

\section{Table 2}

Descriptions of standardized fly trapping sites

\begin{tabular}{|lllll|}
\hline Site Name & Latitude & Longitude & City & Habitat type $^{\text {a }}$ \\
\hline Sunnyvale & $37^{\circ} 21^{\prime} 56^{\prime \prime}$ & $122^{\circ} 00^{\prime} 43^{\prime \prime}$ & Sunnyvale & Urban \\
Alum Rock Park & $37^{\circ} 23^{\prime} 52^{\prime \prime}$ & $121^{\circ} 47^{\prime} 59^{\prime \prime}$ & San José & $\begin{array}{l}\text { Coastal Scrub / Coastal } \\
\text { Oak Woodland }\end{array}$ \\
Grant Ranch & $37^{\circ} 20^{\prime} 35^{\prime \prime}$ & $121^{\circ} 42^{\prime} 56^{\prime \prime}$ & San José & $\begin{array}{l}\text { Coastal Oak Woodland } \\
\text { / Unknown Shrub Type }\end{array}$ \\
San José State University & $37^{\circ} 20^{\prime} 09^{\prime \prime}$ & $121^{\circ} 52^{\prime} 49^{\prime \prime}$ & San José & Urban \\
Skyline & $37^{\circ} 13^{\prime} 50^{\prime \prime}$ & $122^{\circ} 05^{\prime} 44^{\prime \prime}$ & Saratoga & $\begin{array}{l}\text { Redwood / Unknown } \\
\text { Conifer Type }\end{array}$ \\
\hline
\end{tabular}

a Habitat types are as categorized by the California Department of Forestry and Fire Protection's Fire and Resource Assessment Program (FRAP) [47]. 


\subsection{Survey $2010-2011$}

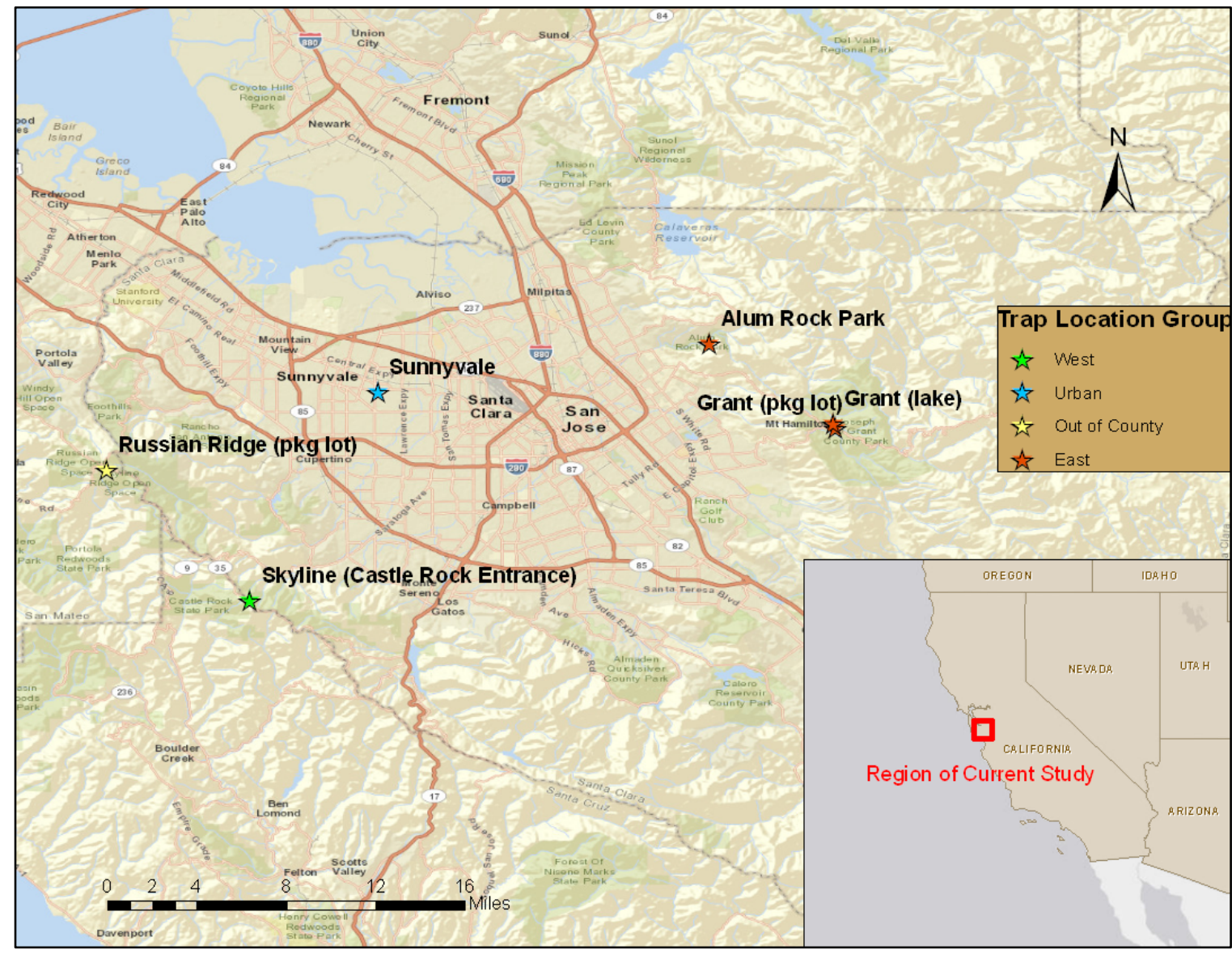

Fig. 1. Location of fly traps set regularly from July 2010 through June 2011. The Russian Ridge trapping site was located in San Mateo County. Although some flies trapped from this out-of-county site were processed for DNA sequencing, they were excluded from summaries or analysis of collection data.

Based on the results obtained through the pilot studies, a 12-month survey was conducted from July 2010 through June 2011. On a monthly basis, or semi-monthly basis when weather permitted, a set of at least two traps were set out at each of two distinct sites in diverse areas of the county (Figure 1): at Sanborn-Skyline County Park in Saratoga ("Skyline”), and near Grant Lake in Joseph D. Grant County Park ("Grant”) adjacent to the city of San José. These two sites were selected in order to target any 
remaining uncollected species of calliphorids; these species were determined to be most likely found in high altitude and/or rural areas near the eastern and western boundaries of Santa Clara County.

Additionally, traps were set approximately bi-monthly at two of the most productive sites trapped previously in the first round of trapping: in the residential backyard in Sunnyvale, and at Alum Rock Park in San José. These two locations received additional trapping to ensure sufficient sampling during all seasons in these areas, as well as to test whether the use of different bait types attracted any previously uncollected species of flies.

The 2010-2011 trapping regimen had the dual purpose of starting a baseline collection of forensically significant sarcophagid and muscid species in the region, as well as capturing additional calliphorid species, as these were areas of the county not previously trapped year-round for this project. Since no previous studies have actively catalogued local sarcophagid or muscid species, this round of trapping also served to capture a preliminary representation of the sarcophagid and muscid communities.

Following the success of the fish baits used in the pilot study, Atlantic herring (received flash-frozen, then thawed and allowed to decompose for two weeks) was the predominant bait type used, although spoiled food-grade beef, chicken, and ground turkey were alternately set in different traps at the same time as the fish-baited traps for most standard trapping events from July 2010 to June 2011. 
Traps were hung from trees for 24-h periods. Flies were killed by freezing for approximately one hour at $-20^{\circ} \mathrm{C}$. Calliphorids, sarcophagids, and muscids were identified using morphology under a dissecting scope as described in the next section. Any specimens of previously undocumented species were saved for sequencing in $80 \%$ $95 \%$ ethanol and kept at $-20^{\circ} \mathrm{C}$. Fly specimens collected of species described in Brundage et al. [43] were discarded. Collection occurrences of some of the less commonly collected forensic fly species were tracked and recorded.

\subsection{Morphological Identifications}

Identifications were carried out at the San José State University Entomology Laboratory under a dissecting microscope. Calliphorids were identified to species using keys prepared by James [42] and Whitworth [41]. A number of keys were used to identify sarcophagids, including Dahlem and Downes [48], Giroux and Wheeler [49], Guimarães [50], Hall [51], Parker (1919), [52], and Reinhard [53]. Huckett's "The Muscidae of California; exclusive of subfamilies Muscinae and Stomoxyinae" [54] was used to identify muscid species. All fly specimens were preserved in the J. Gordon Edwards Entomology Museum at San José State University.

\subsection{DNA Extraction}

Two different DNA extraction methods were used on flies. For all calliphorids, all muscids, and most sarcophagids, DNA was extracted from two legs per fly, using a variation of the simple DNA extraction method as described in Honda [5]. For some exceptionally large sarcophagid specimens, extractions were performed using only one 
leg. If flies had been stored in ethanol, fly legs were rinsed in $1.5 \mathrm{~mL}$ microcentrifuge tubes by filling with deionized water, letting sit $10 \mathrm{~min}$, then draining water and repeating twice. After completing the rinses, water was removed from the vials to the extent possible by absorbing with small, clean strips of paper towels. In order to effectively grind very small pieces of fly tissue, glass micro-pestles were fashioned in the lab by blunting the tips of disposable glass Pasteur pipettes using a Bunsen burner. Fly legs were ground with this sterile glass pestle in a $1.5 \mathrm{ml}$ tube with $4 \mu \mathrm{l}$ of $20 \mathrm{mg} / \mathrm{ml}$ proteinase K (Qiagen, Germany). After grinding, $50 \mu 1$ of a 5\% Chelex 100 solution (Bio-Rad Laboratories, San Ramon, CA) was added to the tube and incubated in a heating block for at least 90 minutes at $56^{\circ} \mathrm{C}$. The solution was then held at $98^{\circ} \mathrm{C}$ for at least 90 minutes, before being stored at $-20^{\circ} \mathrm{C}$.

DNA from sarcophagids was extracted using a DNeasy Blood \& Tissue Kit (Qiagen, Germany), with a modified protocol based on the manufacturer's instructions. One or two fly legs were pulverized in a $1.5 \mathrm{ml}$ microcentrifuge tube along with $180 \mu \mathrm{l}$ of Buffer ATL and $20 \mu \mathrm{l}$ of proteinase $\mathrm{K}$ using a sterile plastic pestle. The mixture was then incubated for at least 90 minutes at $56^{\circ} \mathrm{C}$, then processed per the remainder of the manufacturer's protocol. The final product was eluted in $100 \mu \mathrm{l}$ Buffer AE, then frozen and held at $-20^{\circ} \mathrm{C}$ until PCR.

\subsection{PCR/Sequencing}

A short (348 bp) section of the COI gene was amplified for calliphorids. Primers were custom manufactured by IDT (Integrated DNA Technologies, Coralville, IA) as 
follows:

C1-J-2495 5'- CAG CTA CTT TAT GAG CTT TAG G -3' (forward)

C1-N-2800 5'- CAT TTC AAG CTG TGT AAG CAT C -3' (reverse)

Primers used for calliphorid amplification were based on finding that this primer set worked particularly well at amplifying DNA from sub-optimal conditions, such as extractions from dried, decades-old museum specimens [55]. Primers in this set were originally designed and described in Sperling et al. [32].

PCR conditions for calliphorids were adapted from Wallman and Donnellan [56], as described in Honda [5], and were as follows: $0.5 \mu 1$ of $10 \mathrm{mM}$ dNTP mix, $2.5 \mu 1$ of 25 $\mathrm{mM} \mathrm{MgCl} 2,2.5 \mu \mathrm{l}$ of GeneAmp 10x PCR buffer II, $0.15 \mu \mathrm{l}$ of $5 \mathrm{U} / \mu \mathrm{l}$ Amplitaq Gold DNA polymerase (all Applied Biosystems, Foster City, CA), $0.3 \mu 1$ of each primer (10 $\mu \mathrm{M}$ stock), and $2 \mu \mathrm{l}$ of template DNA in a total reaction volume of $25 \mu \mathrm{M}$. Reactions were run on Perkin Elmer 9600 and Eppendorf Mastercycler thermocyclers under the following conditions: initial denaturation at $95^{\circ} \mathrm{C}$ for $10 \mathrm{~min} ; 33$ cycles at $94^{\circ} \mathrm{C}$ for 30 sec, $52^{\circ} \mathrm{C}$ for $1 \mathrm{~min}$, and $72^{\circ} \mathrm{C}$ for $1 \mathrm{~min}$; final incubation at $72^{\circ} \mathrm{C}$ for $5 \mathrm{~min}$; hold at $4{ }^{\circ} \mathrm{C}$.

For sarcophagids and muscids, the $658 \mathrm{bp}$ "barcode" section of the COI gene was selected for amplification using the following primers:

BarC1 5' - TCT CTA CTA ATC ATA AAG ATA TTG G -3’' (forward)

HCO2198-L 5'- TAA ACT TCW GGR TGW CCA AAR AAT CA -3' (reverse) 
Primers used for sarcophagid and muscid PCRs are modified versions of LCO1490-L (5'-GGTCWACWAATCATAAAGATATTGG-3'), and HCO2198-L (5'RAAACTTCWGGRTGWCCAAARAATCA-3') as used in Meiklejohn et al. [44] to sequence sarcophagids, and by Nelson, Wallman, and Dowton [57] to sequence calliphorids. The variation between BarC1 and LCO1490-L was inadvertent; changes were based on a typo that occurred when ordering custom primers for this project. Regardless of this error, primers used in this study effectively amplified the appropriate section of the COI gene. Primers LCO1490-L and HCO2198-L are themselves modifications of a primer set designed by Folmer et al. [58] as a "universal" set of primers which can be used to sequence a broad variety of invertebrate species. Barcode PCRs were prepared using $1 \mu \mathrm{l}$ of $10 \mathrm{mM}$ dNTP mix, $2 \mu \mathrm{l}$ of $25 \mathrm{mM} \mathrm{MgCl}_{2}, 2 \mu \mathrm{l}$ of GeneAmp 10x PCR buffer II, $0.24 \mu \mathrm{l}$ of $5 \mathrm{U} / \mu \mathrm{l}$ Amplitaq Gold DNA polymerase (all Applied Biosystems, Foster City, CA), $400 \mathrm{nM}$ of each primer, and $1 \mu \mathrm{l}$ of template DNA in a total reaction volume of $20 \mu \mathrm{l}$. Reactions were run under the following conditions: initial denaturation at $94^{\circ} \mathrm{C}$ for $2 \mathrm{~min} ; 30$ cycles at $94^{\circ} \mathrm{C}$ for $30 \mathrm{sec}, 51^{\circ} \mathrm{C}$ for $30 \mathrm{sec}$, and $72^{\circ} \mathrm{C}$ for $2 \mathrm{~min}$; final incubation at $72^{\circ} \mathrm{C}$ for $5 \mathrm{~min}$; hold at $4^{\circ} \mathrm{C}$.

PCR products from all flies were visualized using $1 \%$ agarose gel electrophoresis in TAE (Tris-acetate-EDTA) buffer, stained with ethidium bromide, on a UV light transilluminator. When PCR products showed traces of non-specific amplification fragments (appearing as "smears" on the gel), the target PCR fragments were removed from the gel using a clean scalpel and processed using the QIAquick Gel Extraction Kit (Qiagen, Germany). These gel extractions were then used as template DNA in 
subsequent PCR reactions, which resulted in clean amplifications. Successful amplifications were purified using a DNA Clean \& Concentrator kit (Zymo Research, Irvine, CA).

Sequencing was performed using Applied Biosystems 3730xl DNA Analyzers by Geneway Research in Hayward, CA (flies collected 2005-2008) and by Sequetech in Mountain View, CA (flies collected 2010-2011).

Sequences were analyzed in the Molecular Evolutionary Genetics Analysis (MEGA) software tool. Alignments were prepared with CLUSTAL W [59] using default settings. Registered sequences for flies in GenBank similar to nucleotide sequences of flies in the current study were obtained by using the Basic Local Alignment Search Tool (BLAST) online. Sequence divergences were calculated in MEGA using the Kimuratwo-parameter (K2P) [60] distance model. 


\section{Results}

\subsection{Calliphoridae Collection}

Over the sampling period, sixteen species of calliphorid flies were collected, including Calliphora grahami (Aldrich 1930), Calliphora latifrons (Hough 1899), Calliphora terraenovae (Macquart 1851), Calliphora vicina (Robineau-Desvoidy 1830), Calliphora vomitoria (Linnaeus 1758), Chrysomya rufifiacies (Macquart 1842), Cochliomyia macellaria (Fabricius 1775), Compsomyiops callipes (Bigot 1877), Cynomya cadaverina (Robineau-Desvoidy 1830), Lucilia cuprina (Wiedemann 1826), Lucilia mexicana (Macquart 1843), Lucilia sericata (Meigen 1826), Lucilia silvarum (Meigen 1826), Lucilia thatuna (Shannon 1926), and Phormia regina (Meigen 1826). Earthworm parasitoid Pollenia rudis (Fabricus 1794) was also collected in traps over the sampling period, but was not included in this study, as it is not a species of forensic significance.

Eight species of calliphorids that were not previously found in the regional study by Brundage et al. [43] were collected in this survey. The historical local presence of most of these fly species has been previously recorded by James [42]. Calliphora coloradensis (Hough 1899) and C. livida (Hall 1948), two species documented in the county in the 1955 study, were not found in either of the more recent surveys. However, two of the species collected in the current study, Chrysomya rufifacies and Cynomya cadaverina, represent new records for Santa Clara County (Table 3). 
Table 3

Species checklist of forensically significant calliphorid flies recorded in previous and current studies (adapted in part from Brundage et al. [43]).

\begin{tabular}{|c|c|c|c|c|c|c|}
\hline \multirow{2}{*}{ Species } & \multirow{2}{*}{$\begin{array}{l}\text { Current } \\
\text { Study }\end{array}$} & \multirow{2}{*}{$\begin{array}{l}\text { Brundage } \\
\text { et al. [43] }\end{array}$} & \multicolumn{4}{|c|}{ James [42] } \\
\hline & & & $\begin{array}{l}\text { Santa Clara } \\
\text { County }\end{array}$ & $\begin{array}{l}\text { Alameda } \\
\text { County }\end{array}$ & $\begin{array}{l}\text { San Mateo } \\
\text { County }\end{array}$ & $\begin{array}{l}\text { Santa Cruz } \\
\text { County }\end{array}$ \\
\hline Calliphora coloradensis & & & $\mathrm{x}$ & $x$ & & $\mathrm{x}$ \\
\hline Calliphora grahami & $x$ & & $x$ & $x$ & $x$ & $x$ \\
\hline Calliphora latifrons & $x$ & $x$ & $x$ & $x$ & $x$ & $x$ \\
\hline Calliphora livida & & & $x$ & & $x$ & $x$ \\
\hline Calliphora terraenovae & $x$ & & & $x$ & $x$ & \\
\hline Calliphora vicina ${ }^{a}$ & $x$ & & & $x$ & $x$ & $x$ \\
\hline Calliphora vomitoria & $x$ & $x$ & $x$ & $x$ & $x$ & $x$ \\
\hline Chrysomya rufifacies $^{b}$ & $x$ & & & & & \\
\hline Cochliomyia macellaria & $x$ & & $x$ & $x$ & & \\
\hline Compsomyiops callipes & $x$ & $x$ & $x$ & $x$ & $x$ & $x$ \\
\hline Cynomya cadaverina & $x$ & & & $x$ & & \\
\hline Lucilia cuprina & $x$ & $x$ & $x$ & & $x$ & \\
\hline Lucilia elongata & & & & & $x$ & \\
\hline Lucilia mexicana & $x$ & $x$ & & & & \\
\hline Lucilia sericata & $x$ & $x$ & $x$ & $x$ & & \\
\hline Lucilia silvarum & $x$ & & $x$ & $x$ & $x$ & \\
\hline Lucilia thatuna & $x$ & & $x$ & $x$ & & \\
\hline Phormia regina & $x$ & $x$ & $x$ & $x$ & $x$ & $x$ \\
\hline
\end{tabular}

${ }^{a}$ Calliphora vicina was collected only from San Mateo County in the current study; ${ }^{\mathrm{b}}$ Species in bold represent new county records. Names used for flies are as delineated in Whitworth [41].

One species of calliphorid included in the current survey, Calliphora vicina, was not physically collected in Santa Clara County. During the survey period, eggs from this fly were collected from a vulture carcass in a residential area in nearby San Mateo County. Genetic material was extracted from these samples, and the resulting sequences included in DNA analysis. The failure to detect $C$. vicina in Santa Clara County was 
consistent with the previous findings of both James [42] and Brundage et al. [43].

Calliphora livida, recorded in Santa Clara County by James [42], but not Brundage et al. [43], was not found in this study. An additional species of fly with museum records in Santa Clara County, Calliphora coloradensis, was also absent from traps in the current study. Calliphora coloradensis was not found by either James [42] or Brundage et al. [43].

\subsection{Morphological Identification of Calliphoridae}

Most species of calliphoridae were easily identified using taxonomic keys by Whitworth [41] based on morphological features. The exceptions were two flies in the genus Lucilia that proved problematic to differentiate due to their very similar physical appearance. Though Lucilia sericata and L. thatuna were found in this case to be clearly distinguishable using DNA analysis, definitive identification of all specimens using physical features is still highly desirable.

It was determined that certain differences on the heads of these flies are the clearest characteristics to use to distinguish $L$. sericata from L. thatuna. As shown in Figure 3, white lines have been drawn in to illustrate that the leading edge of the eyes of L. sericata are further away from the frontal suture, compared to L. thatuna. The first flagellomeres (F, in Figure 2) are cupped and reddish in L. thatuna; in L. sericata, the structures are black and the interior surface flat-edged. Although there is some variation between individual specimens, the entire coloration of the gena, or "cheeks," of $L$. thatuna tends to be darker and more reddish than that of the more silver-faced L. sericata. 

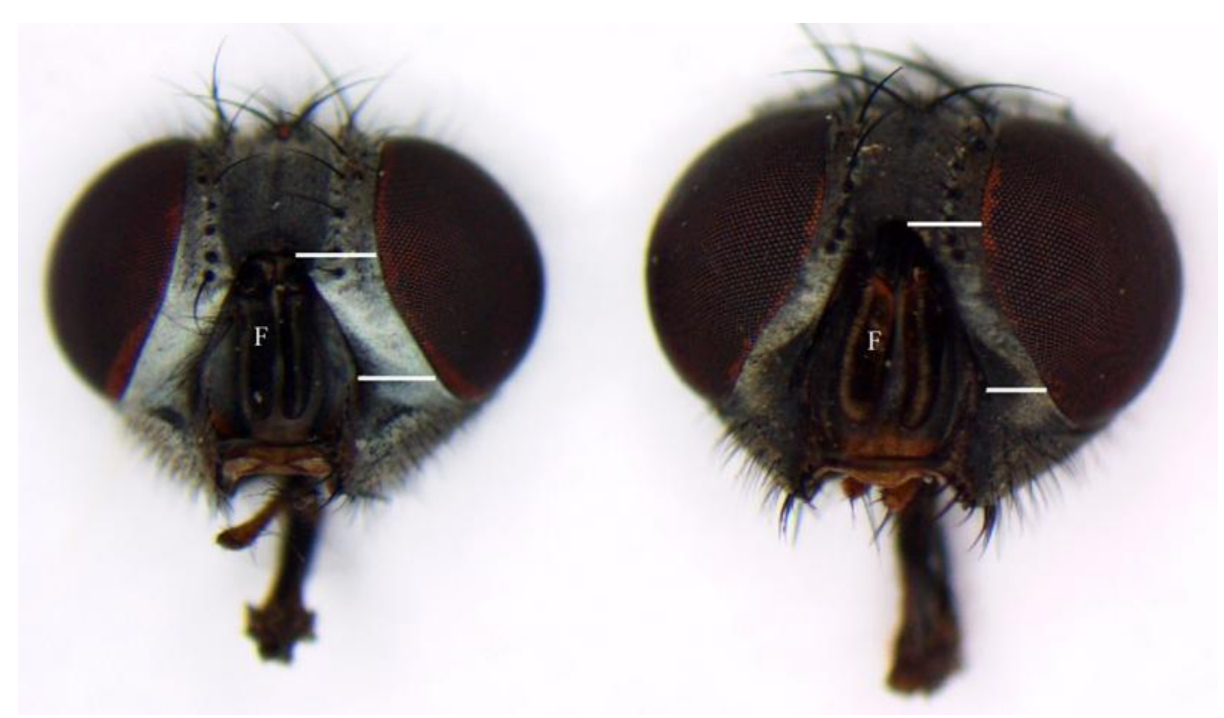

Fig. 2. Comparison of Lucilia sericata and Lucilia thatuna. Lucilia sericata (left) and L. thatuna (right) heads show distinguishing characters including: reddish, cupped flagellar (F) segment in L. thatuna and longer frontal orbital distance between edge of eye and frontal suture in L. sericata. Note also more pronounced black colored frontal orbital area in L. thatuna.

\subsection{DNA Analysis of Calliphoridae}

A section of COI was successfully amplified and sequenced from 51 calliphorids, resulting in 15 species. Whereas this process was not a problem for most specimens, multiple Lucilia mexicana flies failed to yield clean sequences despite repeated attempts at all phases of extraction and PCR. A successful sequence was eventually obtained by extracting DNA from a large section of the fly's abdomen instead of using only the normal two legs. On some occasions for specimens of a variety of species, small nontarget DNA fragments were visualized along with the target DNA segment on the gel during electrophoresis. In these instances, the target segment of DNA was identified by fragment length and cut out of the gel, purified, and re-amplified as described previously.

Comparisons to genetic sequences of calliphorids available in GenBank validated both the morphological identifications and the DNA sequencing methodology used in the 
current study. According to the standards established in Hebert, Cywinska, Ball, and deWaard [61], sequence divergence between different species is expected to be greater than $3 \%$, while the variation among individuals of the same species less than $3 \%$. As shown in Table 4, the genetic divergence between sequences of calliphorids collected in the current survey and closest-match sequences of flies identified as the same species obtained from GenBank varied between $0.000(0.0 \%)$ and $0.021(2.1 \%)$, well within the threshold for same-species variation [61]. Although there were several sequences of fly species obtained from GenBank diverging more than 3\% from sequences of the same species of flies from the current study, many of these GenBank sequences also had a high divergence from the majority of other GenBank sequences identified as the same species, throwing into question the integrity of their original identifications.

Some species of calliphorids identified and sequenced in the current study did not have sequences identified as the same species available in GenBank. Notably, GenBank has no COI sequences identified as Calliphora terraenovae available, yet individual $C$. terraenovae flies trapped in the current study were successfully keyed out and sequenced. When run through a BLAST search, a small number of nearly exact sequence matches were made to GenBank specimens identified as Calliphora vomitoria. However, the GenBank " $C$. vomitoria" that had sequences aligning with this study's $C$. terraenovae diverged from both $C$. vomitoria identified in the current study and other GenBank $C$. vomitoria sequences by a significant amount (>3\%).

\section{Table 4}

Genetic distances (K2P percentage divergences) between calliphorids sequenced in the current study and sequences obtained from GenBank. 


\begin{tabular}{|c|c|c|c|c|c|}
\hline $\begin{array}{l}\text { Current Study } \\
\text { (coll. date) }\end{array}$ & $\begin{array}{l}\text { GenBank } \\
\text { Sequence }\end{array}$ & $\begin{array}{l}\text { Genetic } \\
\text { Distance }\end{array}$ & $\begin{array}{l}\text { Current Study } \\
\text { (coll. date) }\end{array}$ & $\begin{array}{l}\text { GenBank } \\
\text { Sequence }\end{array}$ & $\begin{array}{l}\text { Genetic } \\
\text { Distance }\end{array}$ \\
\hline $\begin{array}{l}\text { C. grahami } \\
(11 / 13 / 10) \\
\text { KF030472 } \\
\end{array}$ & $\begin{array}{l}\text { C. grahami } \\
\text { EU880182 }\end{array}$ & 0.000 & $\begin{array}{l}\text { C. cadaverina } \\
(10 / 28 / 10) \\
\text { KF030483 }\end{array}$ & $\begin{array}{l}\text { C. cadaverina } \\
\text { GQ223326 }\end{array}$ & 0.008 \\
\hline $\begin{array}{l}\text { C. latifrons } \\
(2 / 6 / 05) \\
\text { KF030480 }\end{array}$ & $\begin{array}{l}\text { C. latrifrons } \\
\text { AF295557 }\end{array}$ & 0.000 & $\begin{array}{l}\text { L. cuprina } \\
(5 / 5 / 05) \\
\text { KF030477 } \\
\end{array}$ & $\begin{array}{l}\text { L. cuprina } \\
\text { EF472503 }\end{array}$ & 0.000 \\
\hline $\begin{array}{l}\text { C. vicina } \\
(10 / 26 / 05) \\
\text { KF030471 } \\
\end{array}$ & $\begin{array}{l}\text { C. vicina } \\
\text { EU880192 }\end{array}$ & 0.000 & $\begin{array}{l}\text { L. mexicana } \\
(10 / 19 / 05) \\
\text { KF030476 }\end{array}$ & $\begin{array}{l}\text { L. mexicana } \\
\text { JQ942470 }\end{array}$ & 0.008 \\
\hline $\begin{array}{l}\text { C. vomitoria } \\
(11.29 / 05) \\
\text { KF030469 } \\
\end{array}$ & $\begin{array}{l}\text { C. vomitoria } \\
\text { FR719156 }\end{array}$ & 0.013 & $\begin{array}{l}\text { L. sericata } \\
(4 / 27 / 05) \\
\text { KF030478 } \\
\end{array}$ & $\begin{array}{l}\text { L. sericata } \\
\text { JX913757 }\end{array}$ & 0.008 \\
\hline $\begin{array}{l}\text { C. rufifacies } \\
(10 / 11 / 10) \\
\text { KF030482 } \\
\end{array}$ & $\begin{array}{l}\text { C. rufifacies } \\
\text { EU4185491 }\end{array}$ & 0.000 & $\begin{array}{l}\text { L. silvarum } \\
(7 / 9 / 06) \\
\text { KF030475 }\end{array}$ & $\begin{array}{l}\text { L. silvarum } \\
\text { FJ650564 }\end{array}$ & 0.008 \\
\hline $\begin{array}{l}\text { C. macellaria } \\
(10 / 18 / 05) \\
\text { KF030473 }\end{array}$ & $\begin{array}{l}\text { C. macellaria } \\
\text { AF295555 }\end{array}$ & 0.004 & $\begin{array}{l}\text { L. thatuna } \\
(10 / 11 / 10) \\
\text { KF030474 } \\
\end{array}$ & $\begin{array}{l}\text { L. thatuna } \\
\text { FR719177 }\end{array}$ & 0.000 \\
\hline $\begin{array}{l}\text { C. callipes } \\
(9 / 27 / 05) \\
\text { KF030479 }\end{array}$ & $\begin{array}{l}\text { C. callipes } \\
\text { AF295549 }\end{array}$ & 0.021 & $\begin{array}{l}\text { P. regina } \\
(11 / 5 / 05) \\
\text { KF030481 }\end{array}$ & $\begin{array}{l}\text { P. regina } \\
\text { DQ345078 }\end{array}$ & 0.000 \\
\hline
\end{tabular}

\subsection{Local Distribution of Calliphoridae}

A graph depicting the occurrences of calliphorid fly species that were previously assumed to be rare or nonexistent in the county that were caught in traps during this study is presented in Figure 3, and shows most fly species appear in only very specific seasons, with a general decline in all species during the coldest times of year. Many of the historically less-common species did not occur in high enough numbers to draw meaningful conclusions about their seasonal patterns. However, of the relatively abundant species from this group recorded, C. terraenovae seemed to peak in numbers 
earliest in the year, during late August/early September. Throughout the months of October into early November, C. macellaria and L. thatuna occurred in their highest numbers of the year. Although not recorded in the graph above, only a few individuals of even the very common species of calliphorids were captured in traps from late November through March.

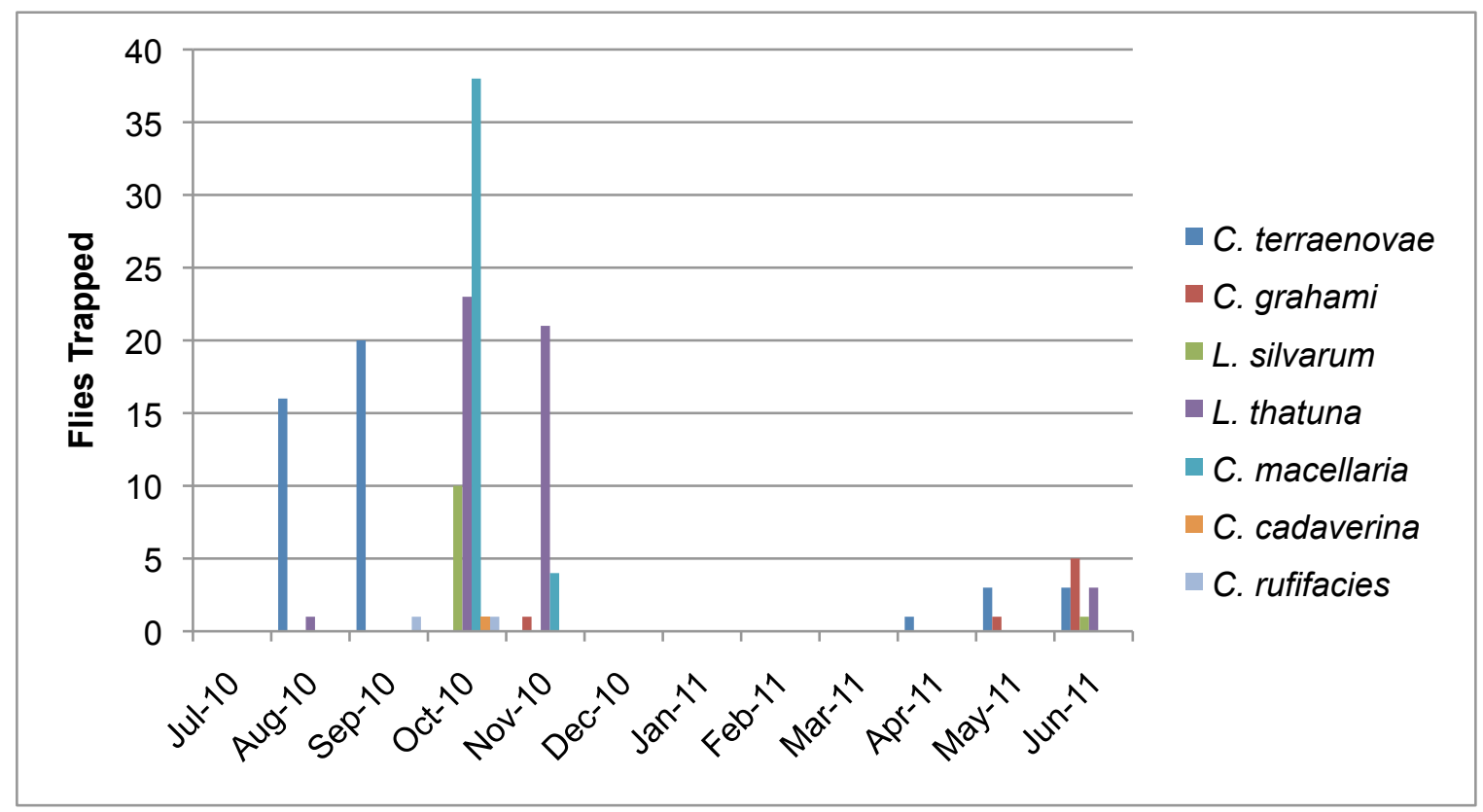

Fig. 3. Trap seasonality of selected calliphorid species. This figure shows the seasonal distribution of trap results for some of the less commonly documented calliphorid flies found in this study from July 2010 through June 2011.

In addition to temporal specificity, the distribution and abundance of these fly species could also be differentiated by habitat and geography. A clear division emerged when traps were categorized as "West County," which included the traps set in the Santa Cruz mountains on Skyline Road near the entrance to Sanborn-Skyline County Park or "East County," composed of traps near Grant Lake at Joseph D. Grant County Park and in Alum Rock Park in San José. As shown in Figure 3, Calliphora terraenovae was 
trapped almost exclusively from the cooler, conifer-shaded Skyline site ("West County:"); the majority of the other infrequently documented flies favored the warmer, drier East County locations. Most of the flies trapped in the East County were collected in areas characterized by exposed oak woodlands in the foothills of the southeast portion of Santa Clara County.

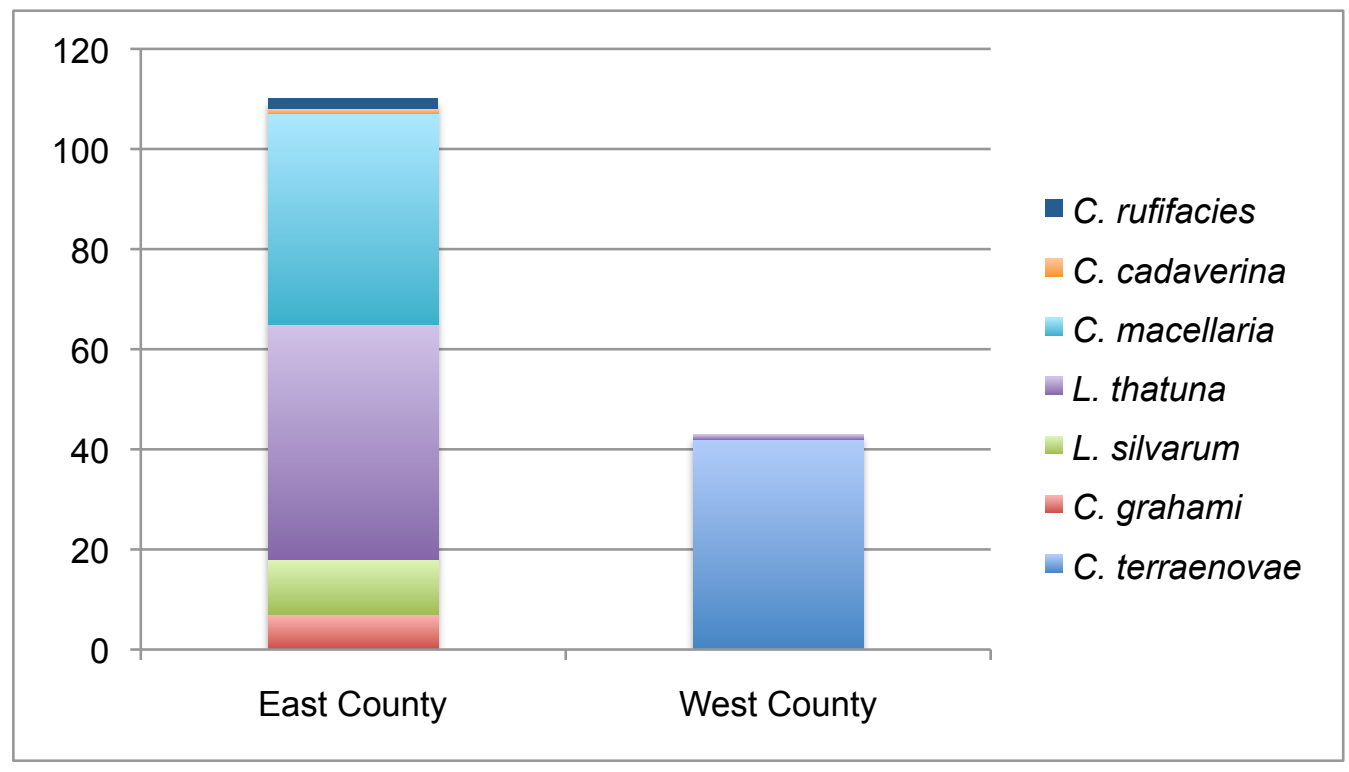

Fig. 4. Distribution of selected calliphorid species. This figure shows the regional distribution of trap results for some of the less commonly documented calliphorid flies found in this study. Notes: A single $C$. terraenovae fly was also trapped in an urban site in Sunnyvale, but is not included in this graph. One $C$. macellaria fly trapped at Evergreen College in the eastern foothills of San José and one C. rufifacies trapped in South San José have been grouped with the East County collections because of the similar habitat characteristics of these sites.

The trap occurrences of these calliphorid species were tested for variation from expected occurrences of these flies in trapping events in the "East County" versus "West County" trap sites. Because of the relatively small sample size of both trapping events and fly species occurring in traps, significance was evaluated using the exact binomial test for goodness-of-fit [62]. Results are shown in Table 5. 
Table 5

Counts of trapping events resulting in captures of four calliphorid species in the east and west sides of Santa Clara County.

\begin{tabular}{|l|r|r|r|r|}
\multicolumn{1}{c}{} & C. macellaria & C. terranovae & L. silvarum & \multicolumn{1}{c|}{ L. thatuna } \\
\hline East County & 42 & 0 & 11 & 47 \\
\hline West County & 0 & 42 & 0 & 1 \\
\hline P-value & $<.001$ & $<.001$ & 0.021 & $<.001$ \\
\hline
\end{tabular}

The trap occurrences of three species of analyzed calliphorids, $C$. macellaria, $L$. silvarum, and L. thatuna, were significantly more likely to be found in a trap in the East County versus the West County $\left(\mathrm{p}=1.18 \times 10^{-7}, 0.020\right.$, and $1.39 \times 10^{-8}$, respectively; $\alpha=$ 0.025). Conversely, C. terraenovae was more likely to be found in traps placed at Skyline $\left(\mathrm{p}=3.40 \times 10^{-21}\right)$. Other species of this selected group of calliphorids did not show a significant correlation to one trapping region or another, or had sample sizes too small for analysis.

Bait preference may have played a role in the diversity of fly species trapped during the study. Whereas C. terraenovae were readily trapped using both fish and nonfish baited traps, L. silvarum and L. thatuna were trapped in much greater numbers using fish bait compared to non-fish baits. Fish-baited traps were also more attractive to the most infrequently-trapped calliphorid species collected during the study. As previously noted, most standardized trapping events from July 2010 to June 2011 at Sunnyvale, Alum Rock, Grant and Skyline sites included both traps baited with fish and non-fish bait. However, there were some instances where only fish bait was used at a trapping event, or traps were destroyed or bait was removed by wildlife, particularly at the Grant Lake trapping site. For this reason statistical analysis was not performed to determine the 
significance of bait selection on species collected. It should also be noted that students in Dr. Jeff Honda's forensic entomology course at San José State University reported collecting individuals of these species of calliphorids using beef-baited traps in different areas of Santa Clara County during the same trapping period as this study (personal communication).

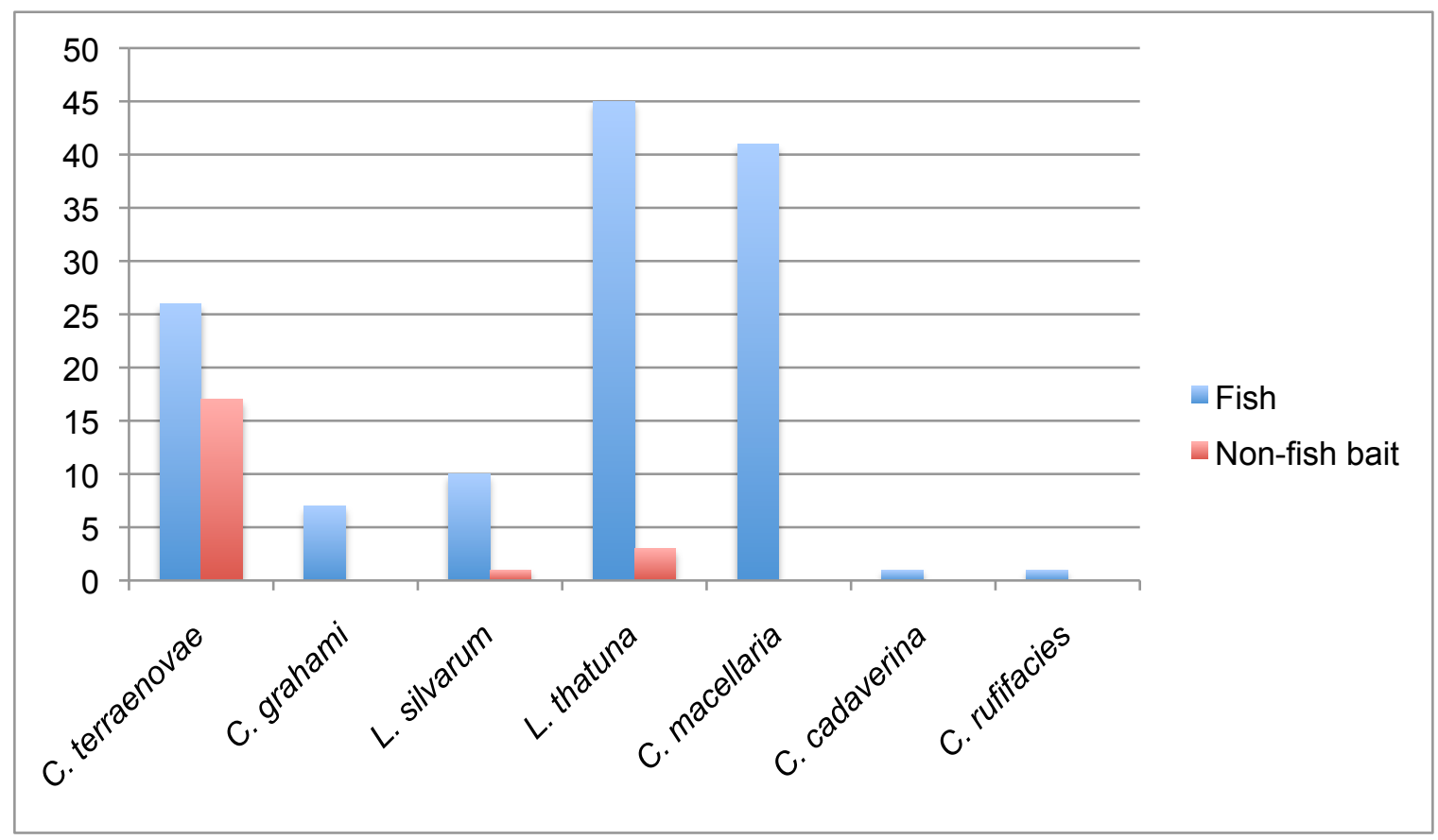

Fig. 5. Captures of selected calliphorid species by bait type. Note: One C. rufifacies and one C. macellaria fly were also trapped using a non-fish (beef) bait, but these collections were not included in this graph, as a fish-baited trap was not set at the same site for comparison.

Two of the calliphorid species trapped represent new records for Santa Clara County. The location of collection sites for Chrysomya rufifacies and Cynomya cadaverina trapped in the current study are pictured in Figure 6. An additional $C$. rufifacies fly was trapped by a San José State University student during the collection period of this study, and is noted separately on the map. 


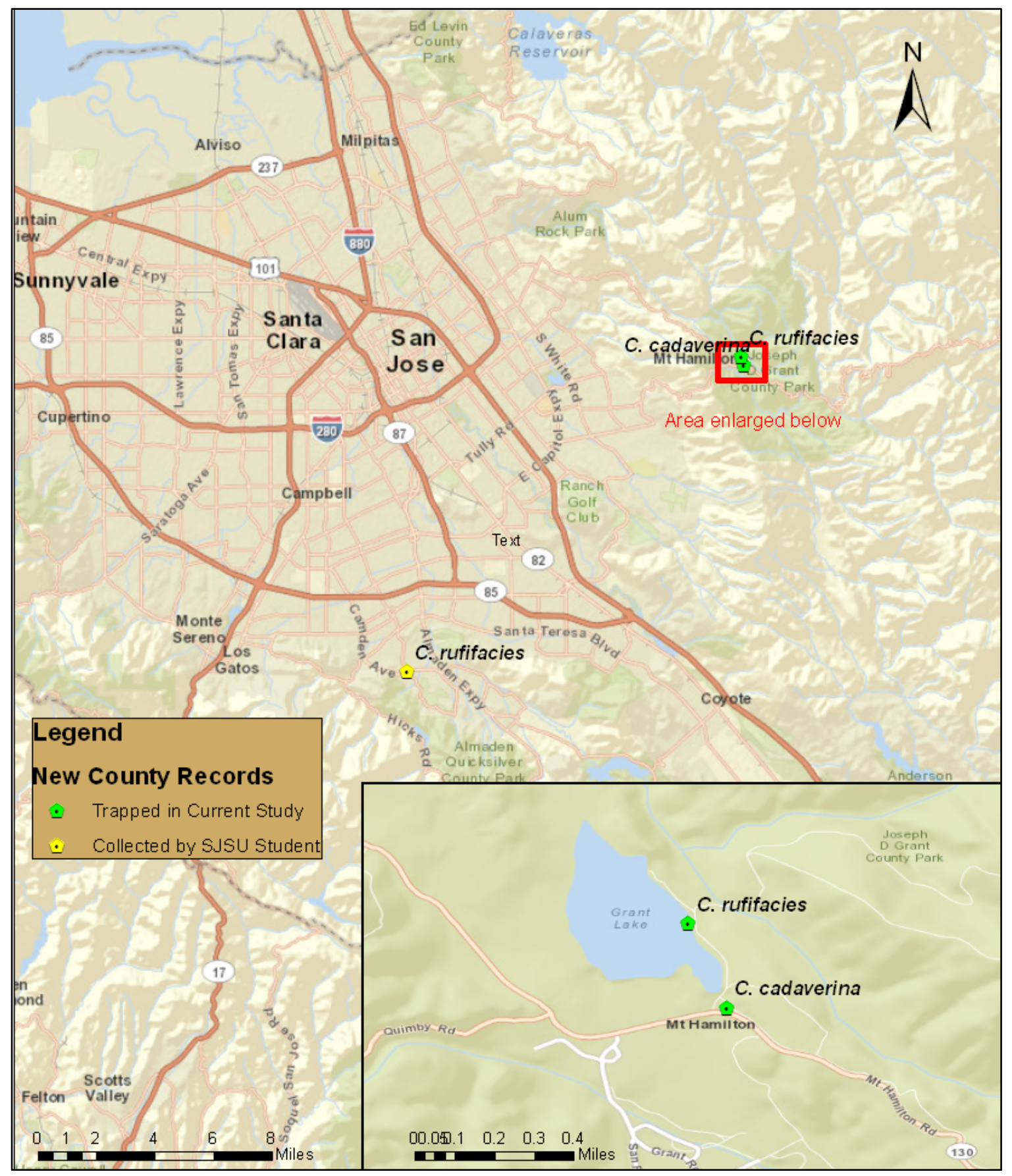

Fig. 6. Location of new county records for species Chrysomya rufifacies and Cynomya cadaverina.

\subsection{Sarcophagidae Collection}


From July, 2010 through June, 2011, at least fourteen species of sarcophagid flies were collected, including Blaesoxipha plinthopyga (Wiedemann 1830), Boettcheria litorosa (Reinhard 1947), Helicobia rapax (Walker 1849), Kellymyia californica (Parker 1918), Liopygia crassipalpis (Macquart 1939), Liosarcophaga sarracenioides (Aldrich 1916), Ravinia querula (Walker 1849), Ravinia stimulans (Walker 1849), Sarcophaga africa (Wiedemann 1824), Sarcophaga bullata (Parker 1916), and Wohlfahrtia vigil (Walker 1849), as well as three unknown, but distinct species: “A," nr. Acanthodotheca reperta (Reinhard 1947), "B," nr. Tripanurga nr. sulcata (Roberts 1931), and "C," nr. Ravinia errabunda (Wulp 1895).

\subsection{Morphological Identification of Sarcophagidae}

Identification of sarcophagid flies using only morphological features proved challenging, as only limited taxonomic keys were available. However, several male specimens were identified as distinct species, based primarily on differences between the reproductive structures. Female sarcophagid flies were unable to be confidently differentiated to species using physical characteristics alone.

\subsection{DNA Analysis of Sarcophagidae}

The "barcode" segment of COI was successfully amplified and sequenced from 103 sarcophagids, representing at least 14 distinct species. As with the calliphorids, genetic distances among individuals identified as the same species of sarcophagids were between 0.000 and 0.015 (Table 6), maintaining consistency with the $<3 \%$ difference standard established in Hebert et al. [61]. However, several species of Sarcophagidae 
identified in this study did not have species name or close sequence matches in Genbank. This may reflect the relatively small number of prior surveys conducted for this family.

Table 6

Genetic distances (K2P percentage divergences) between sarcophagids sequenced in the current study and sequences obtained from GenBank.

\begin{tabular}{|c|c|c|}
\hline $\begin{array}{l}\text { Current Study } \\
\text { (collection date) }\end{array}$ & $\begin{array}{l}\text { GenBank } \\
\text { Sequence }\end{array}$ & $\begin{array}{r}\text { Genetic } \\
\text { Distance }\end{array}$ \\
\hline $\begin{array}{l}\text { B. plinthopyga } \\
(8 / 8 / 10) \\
\text { KF030489 }\end{array}$ & $\begin{array}{l}\text { B. plinthopyga } \\
\text { AF259514 }\end{array}$ & 0.000 \\
\hline $\begin{array}{l}\text { H. rapax } \\
(8 / 23 / 10) \\
\text { KF030492 } \\
\end{array}$ & $\begin{array}{l}\text { H. rapax } \\
\text { GQ223319 }\end{array}$ & 0.015 \\
\hline $\begin{array}{l}\text { L. crassipalpis } \\
(7 / 11 / 10) \\
\text { KF030487 }\end{array}$ & $\begin{array}{l}\text { S. crassipalpis } \\
\text { (= L. crassipalpis) } \\
\text { JN964810 }\end{array}$ & 0.000 \\
\hline $\begin{array}{l}\text { S. bullata } \\
(9 / 21 / 10) \\
\text { KF030488 } \\
\end{array}$ & $\begin{array}{l}\text { S. bullata } \\
\text { GQ223344 }\end{array}$ & 0.000 \\
\hline $\begin{array}{l}\text { R. querula } \\
(7 / 11 / 10) \\
\text { KF030484 } \\
\end{array}$ & $\begin{array}{l}\text { R. Iherminieri } \\
\text { AF259513 }\end{array}$ & 0.000 \\
\hline $\begin{array}{l}\text { R. querula } \\
(7 / 11 / 10) \\
\text { KF030484 } \\
\end{array}$ & $\begin{array}{l}\text { R. querula } \\
\text { GQ223316 }\end{array}$ & 0.000 \\
\hline $\begin{array}{l}\text { S. africa } \\
(7 / 11 / 10) \\
\text { KF030486 }\end{array}$ & $\begin{array}{l}\text { S. africa } \\
\text { JN964710 }\end{array}$ & 0.002 \\
\hline
\end{tabular}

All female sarcophagid flies in suitable condition for DNA extraction were sequenced. Resulting sequences clustered closely enough to form groups of distinct, if unidentified, species. Species identifications were obtained by using BLAST searches to match consensus sequences to sequences of identified male specimens or to sequences filed in GenBank. For example, three male Sarcophaga bullata and nine unidentified 
female sarcophagids sequenced in the current study had genetic distances between 0.000 and 0.003 of one another, but differed from other collected specimens by a genetic distance of at least 0.079 .

Table 7

Genetic distances (K2P percentage divergences) between sarcophagids identified as Sarcophaga bullata sequenced in the current study (CS), selected sequences obtained from GenBank (GB), and a representative sarcophagid identified as Liosarcophaga sarracenioides from the current study.

\begin{tabular}{|c|c|c|c|c|c|c|c|c|c|c|c|}
\hline & Source & Species & $\begin{array}{l}\text { Fly ID } \\
\text { Number }\end{array}$ & 1 & 2 & 3 & 4 & 5 & 6 & 7 & 8 \\
\hline 1 & CS & S. bullata & $\begin{array}{l}\text { KF030488 } \\
(8)^{\mathrm{a}}\end{array}$ & - & & & & & & & \\
\hline 2 & CS & S. bullata & 189 & 0.003 & - & & & & & & \\
\hline 3 & CS & S. bullata & $261(3)^{a}$ & 0.000 & 0.003 & - & & & & & \\
\hline 4 & GB & S. bullata & GQ223344 & 0.000 & 0.003 & 0.000 & - & & & & \\
\hline 5 & GB & N. bullata & JN873919 & 0.024 & 0.027 & 0.024 & 0.024 & - & & & \\
\hline 6 & GB & N. bullata ${ }^{b}$ & JQ246696 & 0.110 & 0.113 & 0.110 & 0.110 & 0.112 & - & & \\
\hline 7 & GB & R. Iherminieri & AF259513 & 0.138 & 0.142 & 0.138 & 0.138 & 0.138 & 0.128 & - & \\
\hline 8 & CS & L. sarracenioides & KF030490 & 0.090 & 0.093 & 0.090 & 0.090 & 0.098 & 0.117 & 0.137 & - \\
\hline
\end{tabular}

\footnotetext{
${ }^{a}$ Numbers in parentheses represent flies of the same sex from this study sharing the same barcode sequence; ${ }^{\text {b }}$ Although GenBank sequence JQ246696 was submitted as Neobellieria bullata (=S. bullata), its sequence varied significantly from other GenBank $S$. bullata, and was likely a different species of fly.
}

As shown in Table 7, when compared to a variety of sequences from GenBank, the consensus male and female $S$. bullata sequences from the current study were exact matches (G.D. $=0.000)$ to GenBank sequence GQ223344, described as Sarcophaga bullata, providing strong evidence to confirm the identification of the nine female sarcophagids. GenBank sequence JN873919 was only a partial COI sequence, and lacked $250 \mathrm{bp}$ when aligned with other sequences in this analysis. Despite this difference, the current study's consensus sequences still met Hebert et al.'s [61] threshold 
( $<3 \%$ divergence) to be considered the same species as JN873919, $N$. bullata (=S. bullata).

\subsection{Local Distribution of Sarcophagidae}

For the purposes of distributional analysis, the Sarcophagidae collected in this study have been divided into two groups. Wells, Pape and Sperling [63] noted that only 9 species of sarcophagids are known to feed on human remains in urbanized areas of the United States. Four of these species, Blaesoxipha plinthopyga, Liopygia crassipalpis, Sarcophaga bullata, and Sarcophaga africa, were collected in this study. The trap seasonality of the forensically significant sarcophagid species is shown in Figure 7, and distribution by location in Figure 8. Sarcophagid species of questionable or unknown forensic significance collected in this study will be considered separately. To compensate for the overall low numbers of flies collected for many of these species, collection data in Figures $7-10$ include hand-collected specimens as well as trap results. 


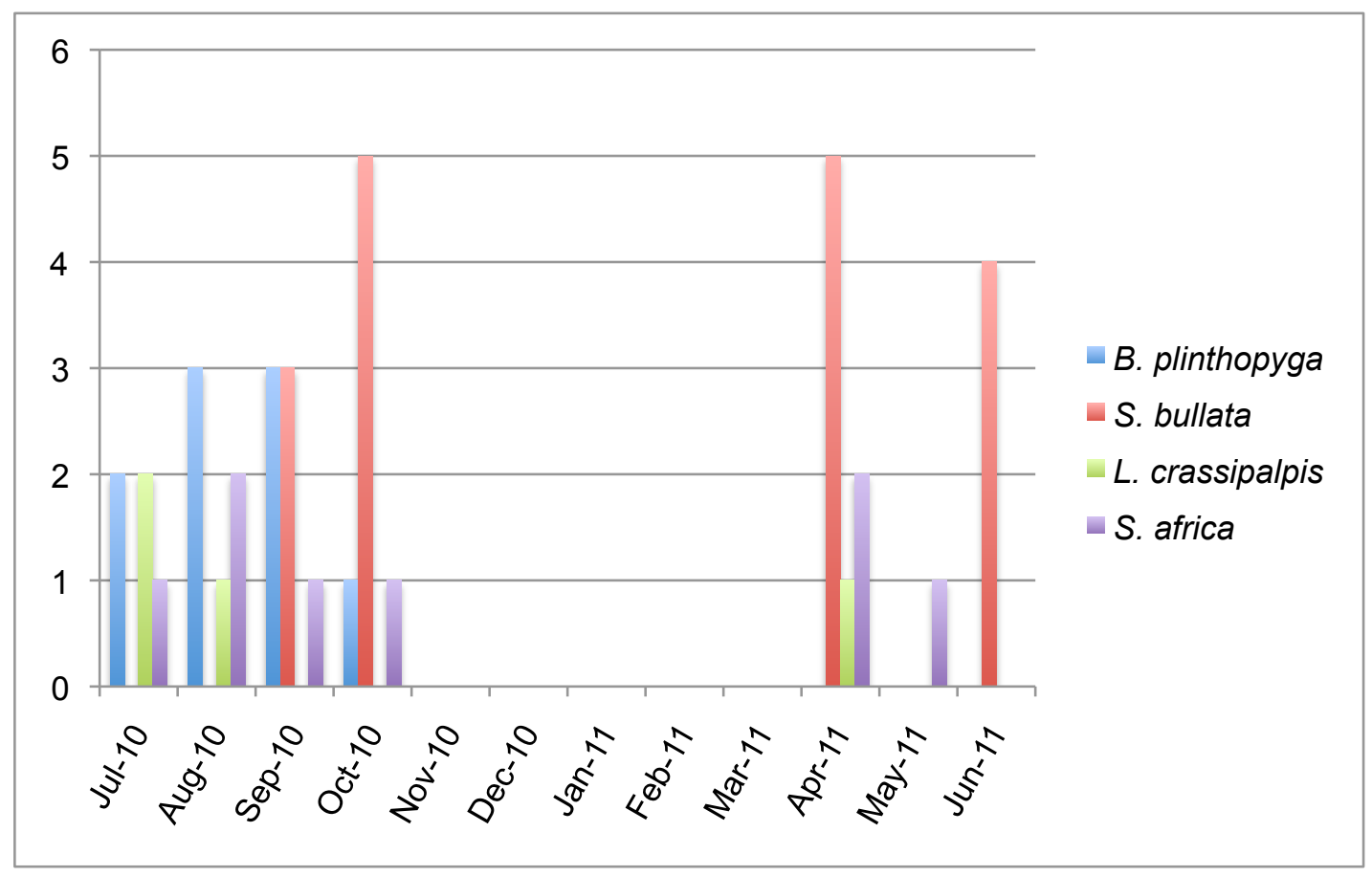

Fig. 7. Seasonal distribution of collections of forensically significant species of sarcophagid flies found in this study (July 2010 - June 2011).

All four forensically significant sarcophagid species were collected in the spring, summer, or autumn months during the July 2010 - June 2011 trapping period.

Collections continued throughout the winter months, yet none of these species were observed from November through March. Blaesoxipha plinthopyga was found in a shorter segment of the collection season compared to the other three fly species and appears in traps only from July through October. 


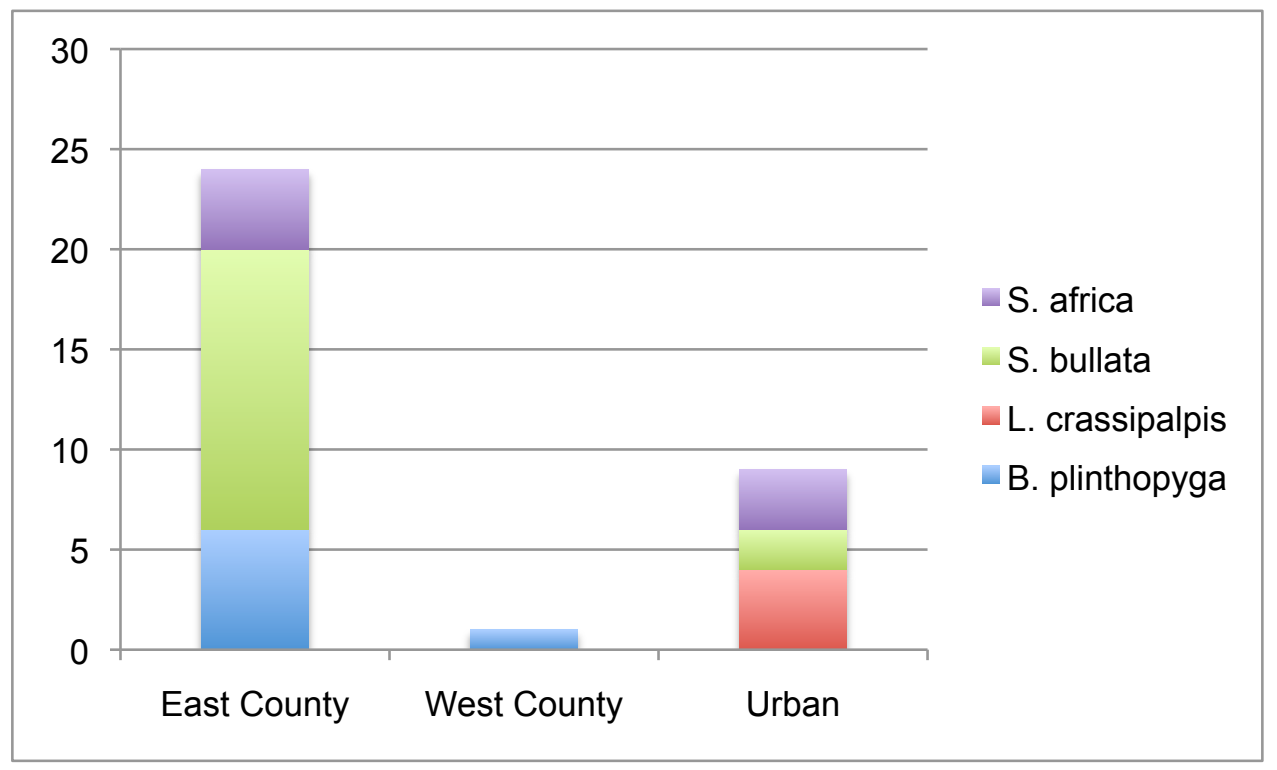

Fig. 8. Collection locations of forensically significant species of sarcophagid flies in this study. "East County" includes Grant and Alum Rock; "West County" includes Skyline; "Urban" includes Sunnyvale and a variety of individual collection sites in and around the San José State University campus.

More forensically significant species of sarcophagids were found in the East and Urban sections of Santa Clara County than in the West (Figure 8). The greatest number of $S$. bullata flies were collected from Grant Ranch, while all S. Africa and the majority of B. plinthopyga specimens came primarily from Alum Rock Park. Liopygia crassipalpis was collected only in Sunnyvale and urbanized areas of San José. Although not included in Figure 8, all forensic sarcophagid species, except for L. crassipalpis, were also trapped in the parking lot of the Russian Ridge Open Space Preserve, located in San Mateo County about nine miles north of the Skyline trapping site (locations shown in Figure 1). 


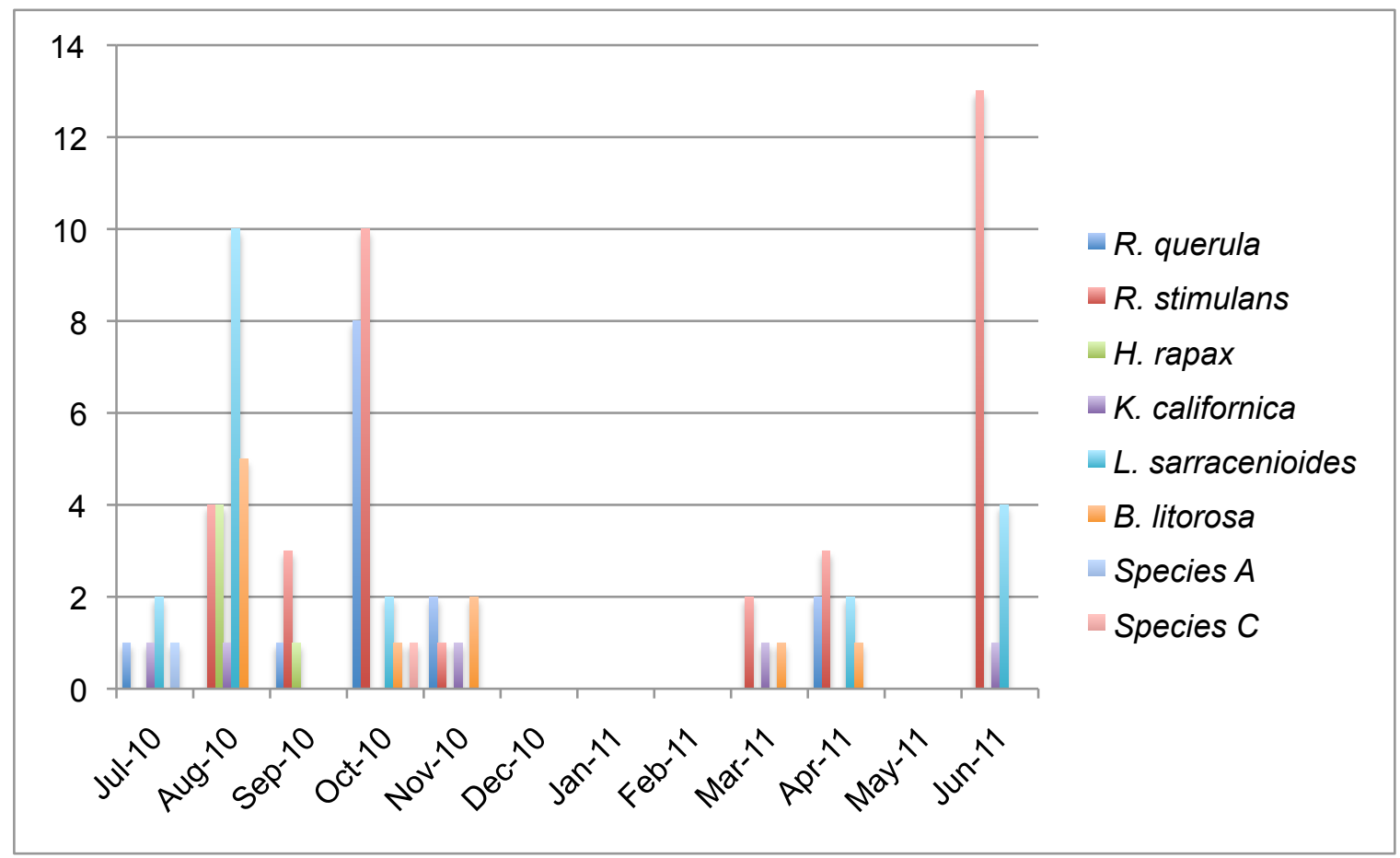

Fig. 9. Seasonal distribution of collections for some of the species of sarcophagid flies of negligible or questionable forensic significance found in this study. "East County" includes Grant and Alum Rock; "West County" includes Skyline; "Urban" includes Sunnyvale and a variety of individual collection sites in and around the San José State University campus.

Consistent to the observed seasonality of the forensically significant species, the remaining eight species of sarcophagids collected in Santa Clara County were collected most often during the warmer months of the year, and disappeared entirely from collections from December through February (Figure 9). Ravinia stimulans was collected during the greatest number of individual months of the collection period. Along with $K$. californica, R. stimulans also appeared to have the longest "season" of activity, from March through November. Some species of flies in this graph had very low collection totals; unknown species A (nr. Acandotheca reperta) and C (nr. R. errabunda) were each represented by a single collected fly. Two individual Wohlfartia vigil flies and a single, unknown fly of Species B (nr. Tripanurga sulcata) were collected from the Russian 
Ridge site in San Mateo County in August 2010, but are not included in Figure 9 or Figure 10.

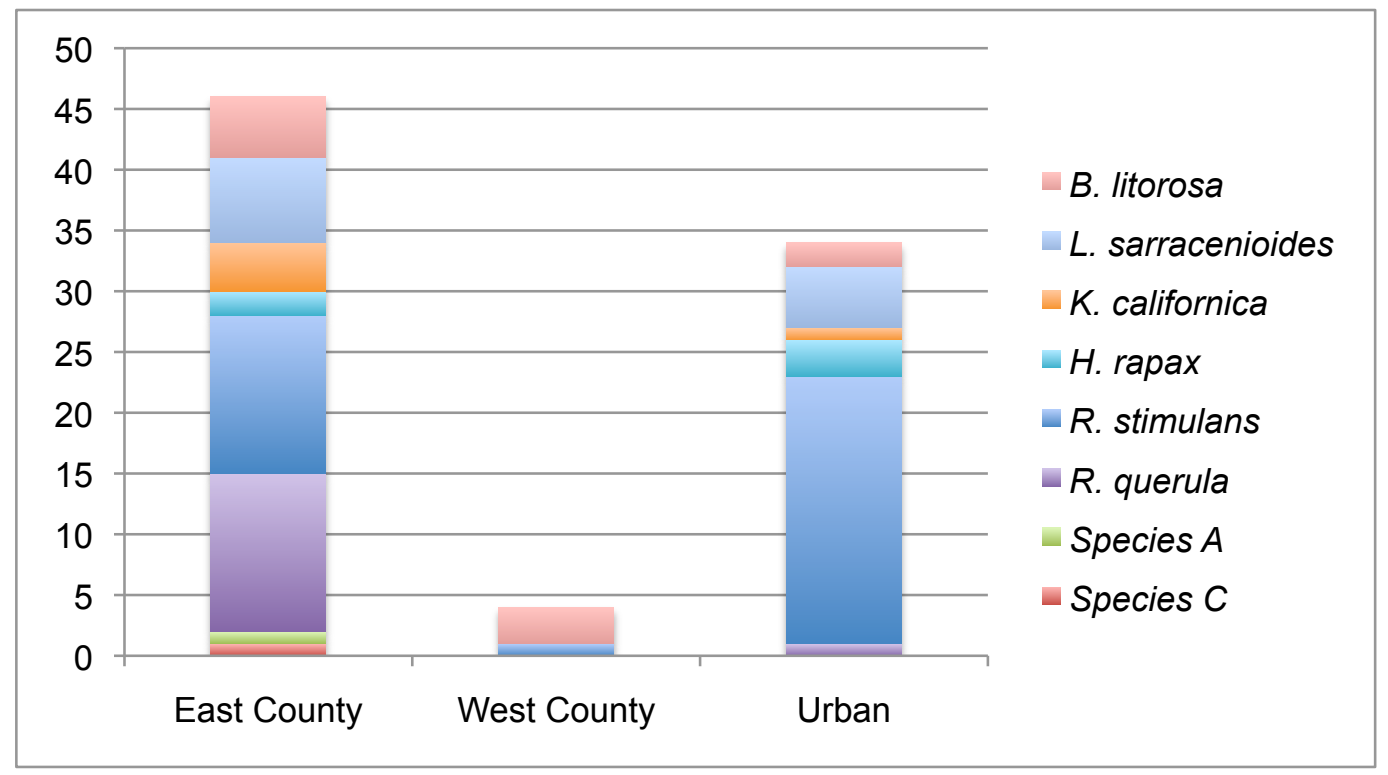

Fig. 10. Locational distribution of trap results for some of the species of sarcophagid flies of negligible or questionable forensic significance found in this study.

As shown in Figure 10, the majority of collections of non-forensic sarcophagids were collected in the East and Urban sections of Santa Clara County. This is a similar pattern to the location of forensic sarcophagids in Figure 8. Two species, R. stimulans and B. litorosa, were found in all three types of collection sites. Although not shown in these graphs, all specimens of these two species from the West County were from a single trap collection in August 2010.

Sarcophagids in this study were attracted to a large variety of bait types. Because many specimens were hand-collected during chance encounters or outside of baited traps, 
collection bias precludes any type of statistical analysis. Table 8 aggregates the types of bait associated with captures of the various sarcophagid species in the current study.

Table 8

Bait associated with sarcophagid collections in the current study.

\begin{tabular}{|c|c|c|c|c|c|c|c|c|c|}
\hline & $\begin{array}{l}\frac{c}{0} \\
\frac{v}{0} \\
\frac{c}{0}\end{array}$ & $\frac{\frac{c}{\omega}}{\frac{1}{2}}$ & 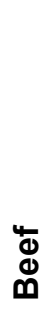 & 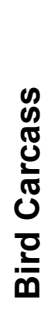 & 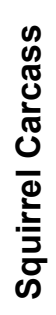 & $\frac{\stackrel{0}{0}}{\frac{\lambda}{\Delta}}$ & 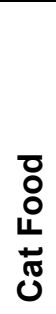 & 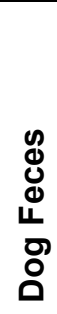 & 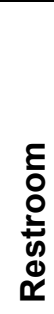 \\
\hline \multicolumn{10}{|l|}{ Forensic Species } \\
\hline B. plinthopyga & $x$ & $\mathrm{X}$ & $\mathrm{x}$ & & & $\mathrm{X}$ & & & \\
\hline L. crassipalpis & & $\mathrm{X}$ & & & & & $X$ & $X$ & \\
\hline S. africa & & $x$ & & & & & $x$ & & \\
\hline S. bullata & $x$ & $x$ & $x$ & $x$ & & & & & \\
\hline \multicolumn{10}{|l|}{ Other Species } \\
\hline B. literosa & $x$ & $x$ & & & & & & & $X$ \\
\hline H. rapax & $\mathrm{X}$ & $\mathrm{X}$ & & & & & & & \\
\hline K. californica & $x$ & $\mathrm{X}$ & $X$ & & & & & & \\
\hline L. sarracenioides & $x$ & $x$ & $x$ & & & $\mathrm{x}$ & & & \\
\hline R. querula & & $x$ & & & $x$ & & $x$ & & \\
\hline R. stimulans & $x$ & $\mathrm{X}$ & & & & & & & \\
\hline W. vigil & & $x$ & & & & & & & \\
\hline Species "A" & $x$ & & $x$ & & & & & & \\
\hline Species "B" & & $X$ & & & & & & & \\
\hline Species "C" & & $\mathrm{X}$ & & & & & & & \\
\hline
\end{tabular}

Almost all species of Sarcophagidae listed in Table 8 were either trapped or handcollected while in the presence of fish bait at least one time in the current study. The exception was unknown species A (nr. Acandotheca reperta), for which only a single collection was made, using a combination of beef and chicken as bait. Because of the 
non-standardized use of different bait types, no verifiable connections can be assessed between different species of sarcophagids and bait preferences.

\subsection{Muscidae Collection}

During the course of sampling for sarcophagids, a number of muscid flies captured in the bottle traps initially appeared to be the common false stable fly, Muscina stabulans (Fallen 1817). However, upon further examination, two additional, morphologically similar species of muscid flies were differentiated from among the collections, Muscina levida (Harris 1780) and Muscina prolapsa (Harris 1780).

Additionally, for a short period of time in the fall, a significant number of Synthesiomyia nudiseta (Wulp 1833) were collected. Since all three of these fly species have no record of being commonly found in this area, occurrences of these fly species in the bottle traps were recorded and tabulated.

\subsection{Morphological Identification of Muscidae}

While all Muscidae considered in this study are superficially similar to $M$. stabulans, the four species of muscids found in this study were straightforward to identify using morphological features (especially antennal and leg characteristics) using keys by Huckett [54]. Some individual flies collected in traps were infested with mites, which were not identified and did not interfere with muscid identification.

\subsection{DNA Analysis of Muscidae}

A section of COI was successfully amplified and sequenced from 13 individual muscid flies, representing four distinct species. Comparison to available sequences of 
Muscidae in GenBank resulted in several close matches confirming morphological identifications of flies from the current study, by the standard set by Hebert et al. [61]. Genetic distances between study and GenBank sequences ranged between 0.006 and 0.011 and are listed in Table 8. No sequences identified as M. prolaps $a$ were available in GenBank, nor did a BLAST search reveal any sequences similar to the sequences obtained from the M. prolapsa collected in the current study.

\section{Table 9}

Genetic distances (K2P percentage divergences) between muscids sequenced in the current study and sequences obtained from GenBank.

\begin{tabular}{|l|l|l|}
\hline $\begin{array}{l}\text { Current Study } \\
\text { (collection date) }\end{array}$ & $\begin{array}{l}\text { GenBank } \\
\text { Sequence }\end{array}$ & $\begin{array}{c}\text { Genetic } \\
\text { Distance }\end{array}$ \\
\hline $\begin{array}{l}\text { M. levida } \\
(10 / 28 / 10) \\
\text { KF030499 }\end{array}$ & $\begin{array}{l}\text { M. assimilis } \\
(=\text { M. levida) } \\
\text { EU627712 }\end{array}$ & 0.008 \\
\hline $\begin{array}{l}\text { M. stabulans } \\
(11 / 2 / 10) \\
\text { KF030501 }\end{array}$ & $\begin{array}{l}\text { M. stabulans } \\
\text { EU627711 }\end{array}$ & 0.006 \\
\hline $\begin{array}{l}\text { S. nudiseta } \\
(8 / 22 / 10) \\
\text { KF030498 }\end{array}$ & $\begin{array}{l}\text { S. nudiseta } \\
\text { EU627713 }\end{array}$ & 0.011 \\
\hline
\end{tabular}

\subsection{Local Distribution of Muscidae}

Figure 11 shows the counts of $S$. nudiseta, M. levida, and M. prolapsa collected in traps by month. As no muscids were hand-collected or collected outside of Santa Clara County over the study period, this graph includes all collections of this fly family evaluated in this study. Muscina stabulans are well-described in the literature as widespread and common; collections of this species were not tabulated in this survey. 


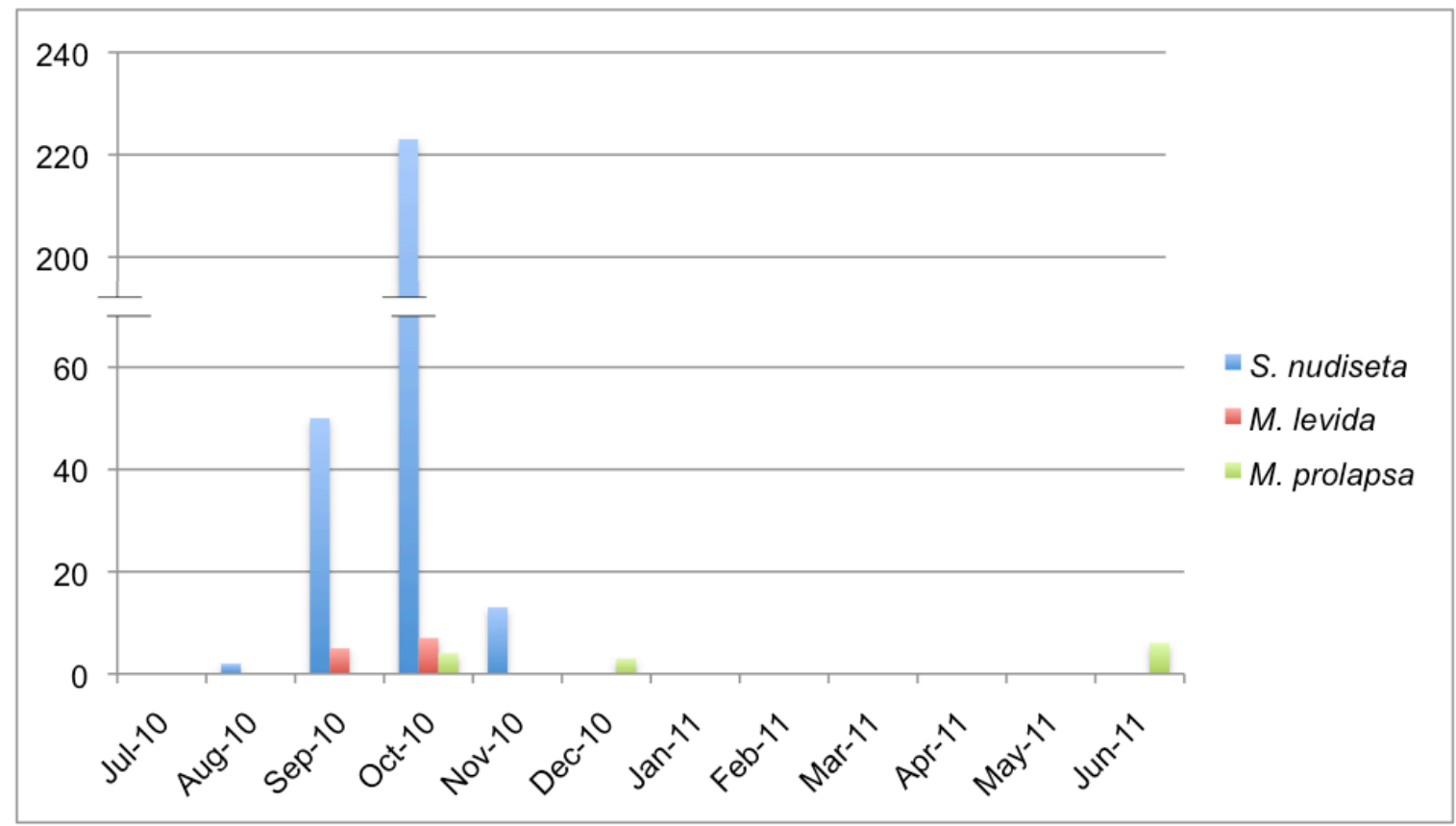

Fig. 11. Seasonal distribution of trap results for some of the species of muscid flies trapped in this study that had previously been assumed to be uncommon in this area.

As demonstrated in Figure 11, examined species of muscids were collected less frequently collected during the colder winter months. However, in contrast to the other fly families, these three species of muscids were collected in traps in a smaller range of months, occurring later in the fall season. Synthesiomyia nudiseta appeared in traps from August through November, with very high counts occurring in October. The other two species of muscids, M. levida and M. prolapsa, were collected in much smaller numbers, making it difficult to draw conclusions on their true seasonality.

None of these three species of muscids were trapped from the Skyline site during the study period. Figure 12 shows the breakdown of specific trap locations (mapped in Figure 1) for collections of each species of fly. 


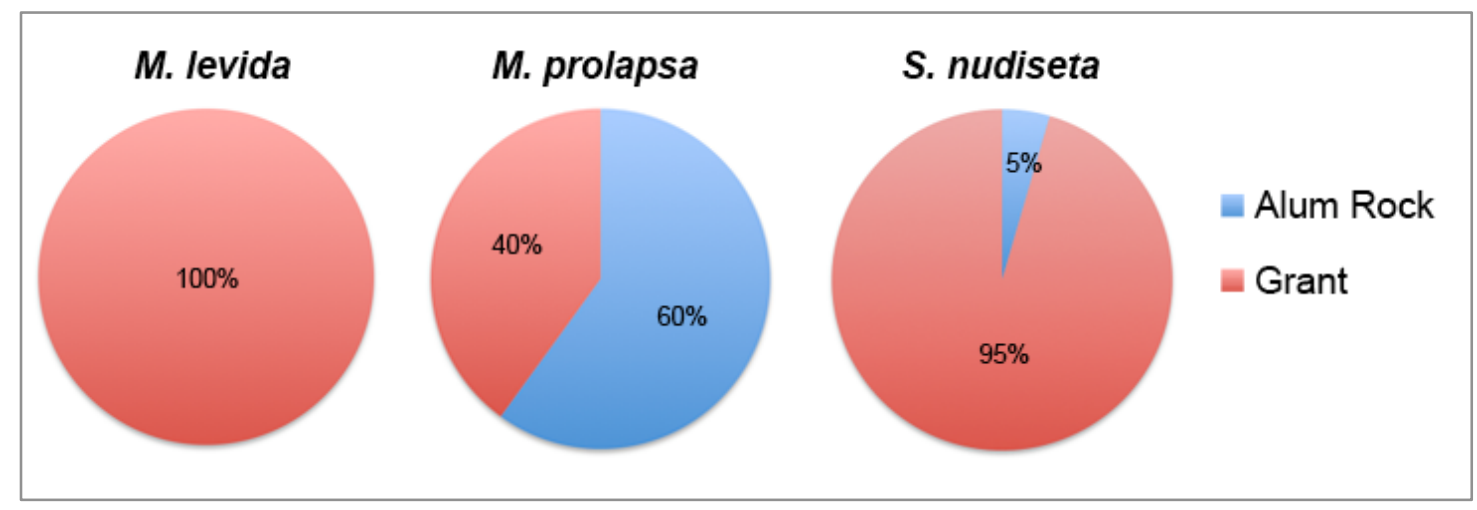

Fig. 12. Trap location breakdown for some of the species of muscid flies trapped in this study that had previously been assumed to be uncommon in this area. Graphs labeled with the percent of flies of each species collected from a given location. Note: A single $S$. nudiseta fly was collected in Sunnyvale, and is not included in this figure. Data from three $M$. prolapsa flies collected on 10/11/10 were also not included in this graph, as the exact location of their collection could not be confirmed.

As shown in Figure 12, all three species of examined muscids were trapped from the Grant Ranch sites. Muscina levida was collected exclusively from this site, whereas M. prolapsa was collected from both Grant and Alum Rock Park. Although S. nudiseta was collected from all three trap sites on the graph, only 13 of the 288 flies of this species came from Alum Rock Park. A single $S$. nudiseta fly was collected from Sunnyvale in August, 2010.

While the survey methodology was not designed to statistically test bait preferences for different species of flies, all three muscid species were trapped in greater numbers using fish compared to chicken. However, the significance of this finding is questionable; during certain trapping events collecting the highest numbers of muscids, due to circumstance and trap failure, only fish bait was available. All three examined species were also collected during the study period using both chicken and fish-baited traps. In some instances, when offered both baits side-by-side, more flies were more 
attracted to one bait versus the other, whereas in others the counts were roughly equal in both types of traps. 


\section{Discussion}

\subsection{Fly Collections}

All calliphorid species previously documented in this Santa Clara County by James [42], with the exception of Calliphora coloradensis, C. livida and the cryptic Melanodexia species, were found in this region. The fly catalogue compiled in the current study included more calliphorid species than those collected by Brundage et al. [43], suggesting that the actual diversity of calliphorids in the Santa Clara County region is higher than that demonstrated in her study. It is likely that variation in collection and identification methods played an important role in the detection of certain species in the current study. Differences between the methodologies in these two studies are summarized in Table 10.

Table 10

Comparison of calliphorid collection methods and results from Santa Clara County used in the current study and in Brundage et al. [43].

\begin{tabular}{|l|l|l|}
\cline { 2 - 3 } \multicolumn{1}{c|}{} & Current Study & Brundage et al. [43] \\
\hline Trap Type & Home-made soda bottle trap & Commercial fly trap \\
\hline Bait & Beef, chicken, and/or fish & Beef liver and water \\
\hline $\begin{array}{l}\text { Trap Frequency (4 regular } \\
\text { trap sites) }\end{array}$ & $\begin{array}{l}\text { Set for 24-h periods, approx. } \\
\text { 2x/month }\end{array}$ & $\begin{array}{l}\text { Left out continuously, } \\
\text { emptied weekly }\end{array}$ \\
\hline Collection period & $\begin{array}{l}\text { Feb 2005 - Oct 2007; } \\
\text { Jul 2010 - Jun 2011 }\end{array}$ & Jan 2001 - Feb 2003 \\
\hline Hand collections included? & \multicolumn{1}{|c|}{ Yes $^{\mathrm{a}}$} & No \\
\hline Species detected & $15^{\mathrm{b}}$ & 8 \\
\hline
\end{tabular}

${ }^{\text {a }}$ Although some species of flies were collected outside of traps, all of the 7 species that were not previously collected by Brundage et al. [43] were caught using baited traps during the 2010-2011 trapping season. ${ }^{\mathrm{b}}$ Calliphora vicina specimens collected in San Mateo County in the current study are not included in this table. 
Notably, the use of fish as bait seemed to expand the variety of species of all three families of flies caught in traps. While a variety of bait types successfully attracted many species, virtually all species of fly collected in this study were caught using fish bait on at least one occasion. Most detections of previously uncollected flies in this study, including the two new county records for calliphorids, occurred using fish-baited traps.

The two calliphorids collected in this study which represent new records in this area, Chrysomya rufifacies and Cynomya cadaverina, have been found in other parts of the state, but not previously in Santa Clara County. According to a survey of museum specimens, C. rufifacies has records from central and southern California [4]. Niemela [4] noted that this species was a rapid colonizer and was likely to be found in other areas of the state, a supposition supported by my findings. Chrysomya rufifacies is known as a secondary colonizer of carrion, and late-stage $C$. rufifacies maggots will feed on other species of fly larvae already present on a carcass, and may interfere with their use in PMI estimation [64]. However, they should be considered forensically significant, per Byrd and Castner [6] and Sukontason [65]. Cynomya cadaverina has also been found sporadically in other parts of California, but generally seems to prefer the higher altitudes and cooler temperatures of the northern areas of the state [4]. Thus, it is somewhat surprising that the only $C$. cadaverina found in the study was trapped on the warmer east side of Santa Clara County. This fly is a known carrion feeder, but its rarity in California limits its forensic application [4]. 
Sarcophagids have been chronically under-studied and as a result are underutilized in forensic entomology [44]. The 11 sarcophagids trapped in the current study establish a preliminary catalogue for Santa Clara County. Niemela [4] found museum records for three forensically significant species of sarcophagids in Santa Clara County, B. plinthopyga, S. bullata, Sarcophaga argyrostoma (Robineau-Desvoidy 1830), and three others in nearby counties: L.crassipalpis, S. Africa, and Sarcophaga cooleyi (Parker 1914). Four of these six species, B. plinthopyga, S. bullata, L. crassipalpis, and S. Africa, were trapped in the current study.

Of the other species of sarcophagids collected, many are known to be coprophagous (Ravinia spp.) or parasitic, and are therefore unlikely species to be used for forensic applications [63]. However, some have potential utility as forensic indicators. Wohfartia are known as scavengers, and some produce myiasis in larger animals, including humans [66]. Helicobia rapax has no documented forensic utility, but was recorded on carrion in a succession study using pig carcasses [67]. The three unknown species collected obviously have uncertain forensic significance; however, unknown species B bore a close morphological resemblance to Tripanurga sulcuta, a species documented as both causing myiasis and breeding in carcasses [68]. Also, all three species were collected with meat-baited traps, they have some level of attraction to carrion, and their life histories merit further investigation.

A larger proportion of sarcophagid species were hand-collected versus trapcollected, compared to other fly families. This may suggest that many of these species 
are attracted to bait but do not actually larviposit directly on carrion (coprophagous species), or are generally more reticent to enter traps. Future surveys of sarcophagids should consider using alternate types of traps or collection methods to maximize captures. As previously noted, rotting fish seems to be a particularly effective attractant for a broad variety of sarcophagid species. Herms found in his 1907 study of Sarcophagidae and beach debris that a fish carcass would attract a large number of flies in as little as 10 to 15 minutes of exposure [69].

Muscids, like the sarcophagids, are utilized less frequently as PMI indicators than are calliphorids. The four muscids trapped in this study, Muscina levida, Muscina prolapsa, Muscina stabulans and Synthesiomyia nudiseta, vary in their biology and larval habits, but all show potential for forensic application. While detailed life histories for many species of Muscina flies are not well-documented, several have been found to be some combination of saprophagous, coprophagous, and zoophagous, including M. levida and M. stabulans $[54,70]$. Greenberg and Kunich [71] specifically report a case where M. levida pupae were found in a car trunk with two human corpses. Muscina prolapsa has been found on buried bodies [72]. Although captures were not specifically tracked in this study, the commonly trapped M. stabulans has documented forensic utility, included a case where bacteria found on pupae helped explain the cause of death of a corpse on which the larvae may have been feeding prior to the individual's death [22].

Despite collection records from Alum Rock in Santa Clara County, the literature refers to $S$. nudiseta as an "uncommon fly" in California, found primarily during the 
summer months [73]. The current study found this fly consistently present at the Grant Ranch trap site only from late August through November, with surprisingly large numbers in October (up to 88 per trap night). In addition to this concentrated seasonality, the majority of trap captures of this fly involved fish bait, consistent with previous documentation of fish as a common oviposition substrate for this fly [74]. However, conclusions regarding bait preference must be drawn cautiously from the current study, for reasons described previously, and in light of other studies in which $S$. nudiseta readily oviposited on beef liver [74, 75]. Synthesiomyia nudiseta has been both used in PMI estimation and has the ability to cause myiasis, and is therefore of considerable forensic interest $[26,76,77]$.

\subsection{Seasonal and Geographic Distribution of Flies}

Microclimates and geographical variation play an important part in the diversity of the fly fauna in this area. The California Department of Forestry and Fire Protection's Fire and Resource Assessment Program (FRAP) identifies over 50 distinct types of wildlife habitats in Santa Clara County [47]. Brundage et al. [43] captured only seven species while trapping in four different areas of Santa Clara County for over two years, compared to 11 or 12 species (exclusive of $P$. rudis and Melanodexia spp.) found in previous studies aggregating museum and historical collection records [4, 42]. The current study, using a combination of regimented trap sites with a variety of bait and opportunistic collections at novel sites, documented fifteen species of calliphorids. In addition to the use of fish bait noted previously, the success of species detection in the current study may be largely attributed to inclusion of these novel collections, as they 
sampled more of the various microclimates of the county. Sites falling into the categories of "rural" and "urban" trapping sites, as defined in Brundage et al. [43], were sampled in both studies. However, the use of different specific sampling sites for the current studies within Brundage's habitat definitions led to sampling of different FRAP-defined microhabitats. As a result, different assemblages of flies were consistently trapped from different trap sites, and represented species not found in previous studies. Current findings support niche partitioning among forensic fly species as described in Brundage et al. [43].

A greater variety of novel fly species of all three families were trapped from the east side versus the west side of Santa Clara County. Although not measured in this survey, a larger overall volume of flies were also observed in traps in the east county. While it is beyond the scope of this study to determine the exact reasons for this disparity, the warmer temperatures and oak woodland and coastal shrub environments associated with the east county sites may have offered a more hospitable environment for many flies. As many in the literature have noted, many forensic species are known to have strong habitat preferences $[4,43]$.

Fly abundance in traps from all three families in this study displayed overlapping seasonal patterns, with collections of examined fly species declining sharply in the winter. The calliphorid C. macellaria (Figure 3) and muscids M. levida and S. nudiseta (Figure 11) were among the most intensely seasonal of flies, with detections in only two or four consecutive months. Many other examined flies appeared in high numbers in 
only one to three consecutive months, but were also encountered occasionally at other times of year. A number of fly species were not collected often enough to meaningfully speculate about their true seasonality. Though not detailed in this paper, it should be noted that many of the "common" calliphorids (e.g. Lucilia sericata, Calliphora vomitoria, and others) trapped during this study also displayed annual cycles of high and low abundance. Seasonal distribution of these flies were previously described in Brundage et al. [43], and were trapped in much greater numbers in the current study than were the novel flies, including captures during winter months when the novel fly species were absent.

Several individual trap events at the west county (Skyline) site were characterized by heavy fog and extremely cold temperatures. On these occasions, no flies, or very few flies, of any family were collected in meat-baited traps. It is unknown whether environmental conditions caused the meat in these traps to be insufficiently attractive to flies during this time, or if flies moved out of the area to seek warmer areas or were simply inactive. These low-yield trap events were distributed throughout the fall, winter and spring, but most common during December and January.

\subsection{Molecular Identifications}

The amplified sections of the COI gene were generally successful in confirming identifications for flies of all three families in the current study. As sarcophagids are notoriously difficult to identify using morphological features, molecular methods are particularly helpful in facilitating and verifying identifications for this fly family. 
Unfortunately, significantly fewer sarcophagid sequences identified to the species level were available on GenBank compared to those of calliphorids and muscids. Jordaens et al. [78] found in a recent GenBank search, that only $12 \%$ of the approximately 800 known Sarcophagid species had COI sequences in GenBank. This is probably due to a combination of lack of focus on sarcophagids for forensic applications and research, and the scarcity of expertise in identifying sarcophagids. In addition to the dearth of banked sarcophagid sequences, COI sequences for the common muscid M. prolapsa were unavailable in GenBank. Whereas other flies of the genus Muscina have been observed in carrion succession studies [70] (and others) and have proved their forensic utility in child abuse cases [79], M. prolapsa does not specifically have not a documented forensic significance, other than observations of myiasis on sheep [80]. The perceived lack of forensic and economic importance may be responsible for the absence of genetic information available for this widespread species.

In addition to molecular identification of flies being limited by the limited number of submitted species in GenBank, analyses in this study also emphasized two confounding issues involved with using genetic barcoding to identify flies: (1) problems with data integrity in GenBank, (2) the inability of a short sequence segment of COI to reliably distinguish certain species of flies. As previously mentioned, DNA sequence comparisons revealed fly sequences retrieved from GenBank that were likely misidentified species, as exemplified by the anomalous GenBank sequence JQ246696 labeled at the time of submission as $N$. bullata (Table 6). GenBank sequences from purportedly identified flies which varied dramatically from those of both GenBank 
consensus sequences and the current study were found repeatedly during this study, and included flies from all three families surveyed. Numerous other studies have commented on similar discoveries of misidentified, mislabeled GenBank sequences [37, 38, 78]. Stricter controls are desperately needed to weed out the submission of unverified, misidentified sequences from GenBank.

The second issue is the occasional failure of the COI barcode sequence to distinguish between flies of different species. In the current study, the particular region of COI amplified from Ravinia querula was a 100\% match to sequences identified from two different species of sarcophagids in GenBank, R. querula and R. lherminieri. What at first appeared to be a data integrity issue is actually an inherent shortcoming of relying upon DNA barcoding alone for species identification. The COI gene has been previously noted as being unable to differentiate these two closely related species of Ravinia in a recent conference presentation [81]. Similar issues with DNA barcoding of the calliphorid genus Protocalliphora have been documented, especially when dealing with paraphyletic species [82]. For the current study, consultation with sarcophagid expert Gregory Dahlem confirmed that of the two species in question, only $R$. querula is found on the West Coast of the United States, and thus the $100 \%$ sequence match to both GenBank sequences identified as $R$. querula and R. lherminieri (Table 6) could be used to confirm the local identification of $R$. querula specimens (Jeffrey Honda, personal communication). In areas such as the midwest, where both species of Ravinia may be present in the same area, additional genetic or morphological analysis would be required for confident identification [83]. A combined approach to verification of species 
identification is the ideal approach to address these challenges, and would include morphological identification of the specimen, application of biological and ecological knowledge, and DNA sequencing of multiple target sequences. 


\section{Conclusion}

The forensically significant fly population of Santa Clara County is diverse and influenced by a variety of factors. Significant differences were found in fly fauna in even this relatively small geographic area, indicating the importance of microclimates in the distribution of these flies. The catalogue of flies found in this study exceeded the previous records of fly species in this area, including finding previously undocumented species and larger-than-expected numbers of calliphorids, sarcophagids, and muscids previously assumed to be uncommon in the area. Flies collected in this study also form the basis for baseline data regarding the collection of of local sarcophagid species, several of which have documented forensic significance. Molecular analysis supports the use of DNA barcoding as an effective method of identifying cryptic fly species, but success of this technique relies upon maintaining a comprehensive and reliable genetic reference catalogue in GenBank or other accessible data aggregation sources. 


\section{$\underline{\text { Literature Cited }}$}

[1] S. Reibe, J. Schmitz, B. Madea. Molecular identification of forensically important blowfly species (Diptera: Calliphoridae) from Germany. Parasitol. Res. 106 (1) (2009) $257-261$.

[2] R. Zehner, J. Amendt, S. Schutt, J. Sauer, R. Krettek, D. Povolny. Genetic identification of forensically important flesh flies (Diptera : Sarcophagidae). Int. J. Legal Med. 118 (4) (2004) 245-247.

[3] A. Brundage. Distribution and abundance of forensically important flies in Santa Clara County [Master's Thesis]: San Jose State University; 2007.

[4] M.K. Niemela. The forensically important flies of California [Master's Thesis]: University of California, Davis; 2007.

[5] J.Y. Honda. Use of the CO I gene as a species indicator for forensically important flies: a forensic entomology laboratory exercise. Bioscene: J. Teach. Col. Biol. 34 (1) (2008) 20-23.

[6] J.H. Byrd, J.L. Castner. Forensic entomology: the utility of arthropods in legal investigations. Boca Raton: CRC Press; 2001.

[7] E. Catts, M.L. Goff. Forensic entomology in criminal investigations. Annu. Rev. Entomol. 37 (1) (1992) 253-272.

[8] B. Keh. Scope and applications of forensic entomology. Annu. Rev. Entomol. 30 (1985) 137-154.

[9] B.E. McKnight. The washing away of wrongs: Forensic medicine in thirteenthcentury China. Ann Arbor: Center for Chinese Studies, The University of Michigan. (1981).

[10] M. Bergeret. Infanticide, momification naturelle du cadavre. Ann. Hyg. Publique Med. Leg. 4 (1855) 442-452. 
[11] P. Brouardel. De la détermination de l'époque de la naissance et de la mort d'un nouveau-née, faite à l'aide de la présence des acares et des chenilles d'aglosses dans cadavre momifié [Determination of the time of birth and of death of a new-born child, made using the presence of mites and Aglossa caterpillars on the mummified corpse]. Ann. Hyg. Publique Med. Leg. 2 (1879) 153-158.

[12] M. Benecke. A brief history of forensic entomology. Forensic Sci. Int. 120 (1-2) (2001) 2-14.

[13] H. Reinhard. Beiträge zur Gräberfauna (Contributions on the fauna of graves). Verh. k. \& k. Zool.-Bot. Ges. Wien. 31 (1882) 207-210.

[14] O. Hofman. Observations de larves de Diptères sur des cadavres exhumés. C. R. Séances Soc. Ent. Belg. 74 (1886).

[15] G.P. Yovanovitch. Entomologie appliquée à la médicine légale: Ollier-Henry; 1888.

[16] P. Mégnin. La faune des cadavres: Application de l'entomologie a la médicine légale: Masson \& Gauthier-Villars; 1894.

[17] W. Johnston, G. Villeneuve. On the medico-legal application of entomology. Montreal. Med. J. 26 (1897) 81-90.

[18] M.G. Motter. A contribution to the study of the fauna of the grave. A study of on hundred and fifty disinterments, with some additional experimental observations. J. N. Y. Entomol. Soc. 6 (4) (1898) 201-231.

[19] J. Maschka. Angeblicher Tod eines Kindes infolge von Verletzungen. Natürliche Todesart. Entstehung der Verletzung nach dem Tod durch Ameisenbisse (Alleged death of a child due to injuries. Natural cause of death. Injury patterns caused by ant bites). Vjschr. Ger. Med. (N. F.). 34 (1881) 193-197.

[20] D. Klingelhöffer. Zweifelhafte Leichenbefunde durch Benagung von Insekten. Vjschr. Ger. Med. 25 (1898) 58-63. 
[21] S. von Horoszkiewicz. Casusistischer Beitrag zur Lehre von der Benagung der Leichen durch Insecten (A case report concerning the feeding of insects on human corpses). Vjschr. Ger. Med. 3 (1902) 235-239.

[22] M. Benecke. Six forensic entomology cases: Description and commentary. J. Forensic Sci. 43 (4) (1998) 797-805.

[23] J. Prichard, P. Kossoris, R. Leibovitch, L. Robertson, F. Lovell. Implications of trombiculid mite bites: report of a case and submission of evidence in a murder trial. J. Forensic Sci. 31 (1) (1986) 301.

[24] J.P. Webb Jr, R.B. Loomis, M.B. Madon, S.G. Bennett, G.E. Greene. The chigger species Eutrombicula belkini Gould (Acari: Trombiculidae) as a forensic tool in a homicide investigation in Ventura County, California. Bull. Soc. Vector Ecol. 8 (2) (1983) 142-146.

[25] W. Lord. Case histories of the use of insects in investigations. In: E.P. Catts, N.H. Haskell, editors. Entomology \& death: a procedural guide. Clemson, SC: Joyce's Print Shop; 1990.

[26] W.D. Lord, T.R. Adkins, E.P. Catts. The use of Synthesiomyia-nudesita (van der Wulp) (Diptera, Muscidae) and Calliphora-vicina (Robineau-Desvoidy) (Diptera, Calliphoridae) to estimate the time of death of a body buried under a house. J. Agr. Entomol. 9 (4) (1992) 227-235.

[27] K. Saigusa, M. Takamiya, Y. Aoki. Species identification of the forensically important flies in Iwate prefecture, Japan based on mitochondrial cytochrome oxidase gene subunit I (COI) sequences. Legal Med. 7 (3) (2005) 175-178.

[28] J.R. Pujol-Luz, P. Francez, A. Ururahy-Rodrigues, R. Constantino. The black soldier-fly, Hermetia illucens (Diptera, Stratiomyidae), used to estimate the postmortem interval in a case in Amapa State, Brazil. J. Forensic Sci. 53 (2) (2008) 476-478.

[29] B. Greenberg, J.D. Wells. Forensic use of Megaselia abdita and M. scalaris (Phoridae: Diptera): case studies, development rates, and egg structure. J. Med. Entomol. 35 (3) (1998) 205-209. 
[30] J.H. Byrd. Laboratory rearing of forensic insects. In: J.H. Byrd, J.L. Castner, editors. Forensic entomology: the utility of arthropods in legal investigations. Boca Raton: CRC Press; 2001. p. 121-142.

[31] S. Vincent, J.M. Vian, M.P. Carlotti. Partial sequencing of the cytochrome oxydase b subunit gene I: a tool for the identification of European species of blow files for postmortem interval estimation. J. Forensic Sci. 45 (4) (2000) 820-823.

[32] F.A.H. Sperling, G.S. Anderson, D.A. Hickey. A DNA-based approach to the identification of insect species used for postmortem interval estimation. J. Forensic Sci. 39 (2) (1994) 418-427.

[33] C. Ames, B. Turner, B. Daniel. The use of mitochondrial cytochrome oxidase I gene (COI) to differentiate two UK blowfly species - Calliphora vicina and Calliphora vomitoria. Forensic Sci. Int. 164 (2-3) (2006) 179-182.

[34] J. Stevens, R. Wall. Genetic relationships between blowflies (Calliphoridae) of forensic importance. Forensic Sci. Int. 120 (1) (2001) 116-123.

[35] J.D. Wells, D.W. Williams. Validation of a DNA-based method for identifying Chrysomyinae (Diptera : Calliphoridae) used in a death investigation. Int. J. Legal Med. 121 (1) (2007) 1-8.

[36] A.M.L. de Azeredo-Espin, A.C. Lessinger. Genetic approaches for studying myiasiscausing flies: molecular markers and mitochondrial genomics. Genetica. 126 (1-2) (2006) $111-131$.

[37] N. Dawnay, R. Ogden, R. McEwing, G.R. Carvalho, R.S. Thorpe. Validation of the barcoding gene COI for use in forensic genetic species identification. Forensic Sci. Int. 173 (1) (2007) 1-6.

[38] S.H. Park, Y. Zhang, H. Piao, D.H. Yu, H.J. Jeong, G.Y. Yoo, et al. Sequences of the Cytochrome C Oxidase Subunit I (COI) gene are suitable for species identification of Korean Calliphorinae flies of forensic importance (Diptera: Calliphoridae). J. Forensic Sci. 54 (5) (2009) 1131-1134. 
[39] J.D. Wells, R. Wall, J.R. Stevens. Phylogenetic analysis of forensically important Lucilia flies based on cytochrome oxidase I sequence: a cautionary tale for forensic species determination. Int. J. Legal Med. 121 (3) (2007) 229-233.

[40] D.G. Hall. Blowflies of North America. Baltimore: Thomas Say Foundation; 1948.

[41] T. Whitworth. Keys to the genera and species of blow flies (Diptera : Calliphoridae) of America North of Mexico. Proc. Entomol. Soc. Wash. 108 (3) (2006) 689-725.

[42] M.T. James. The blowflies of California (Diptera: Calliphoridae). Berkeley: University of California Press; 1955.

[43] A. Brundage, S. Bros, J.Y. Honda. Seasonal and habitat abundance and distribution of some forensically important blow flies (Diptera: Calliphoridae) in Central California. Forensic Sci. Int. 212 (1) (2011) 115-120.

[44] K. Meiklejohn, J. Wallman, M. Dowton. DNA-based identification of forensically important Australian Sarcophagidae (Diptera). Int. J. Legal Med. 125 (1) (2009) 27-32.

[45] A. Ordonez, M.D. Garcia, G. Fagua. Evaluation of efficiency of Schoenly trap for collecting adult sarcosaprophagous dipterans. J. Med. Entomol. 45 (3) (2008) 522-532.

[46] Z.A. Shah, Z. Fatima. Impact of flesh age, trap color and decomposition stage on the population dynamics and species composition of Calliphoridae and Sarcophagidae. Pak. J. Zool. 39 (1) (2007) 45-50.

[47] FRAP: California Department of Forestry and Fire Protection's Fire and Resource Assessment Program. Santa Clara County Wildlife Habitats: Multi-source Land Cover Data2002.

[48] G.A. Dahlem, W.L. Downes Jr. Revision of the genus Boettcheria in America North of Mexico (Diptera: Sarcophagidae). Insecta Mundi. (1996) 8.

[49] M. Giroux, T.A. Wheeler. Systematics and phylogeny of the subgenus Sarcophaga (Neobellieria)(Diptera: Sarcophagidae). Ann. Entomol. Soc. Am. 102 (4) (2009) 567587. 
[50] H.J.L. Guimarães. Redescrição dos machos de dez espécies neotropicais de Ravinia Robineau-Desvoidy, 1863 (Diptera, Sarcophagidae). Arquivos do Museu Nacional. 62 (1) (2004) 45-66.

[51] D.G. Hall. Sarcophaga pallinervis and related species in the Americas. Ann. Entomol. Soc. Am. 21 (2) (1928) 331-352.

[52] R. Parker. New Sarcophagidæ from Asia, with data relating to the dux group. Ann. Mag. Nat. Hist. 11 (61) (1923) 123-129.

[53] H. Reinhard. New North American muscoid Diptera. J. Kansas Entomol. Soc. 20 (3) (1947) 95-116.

[54] H.C. Huckett. The Muscidae of California: exclusive of subfamilies Muscinae and Stomoxyinae: University of California Press; 1975.

[55] J.D. Wells, F.A.H. Sperling. DNA-based identification of forensically important Chrysomyinae (Diptera : Calliphoridae). Forensic Sci. Int. 120 (1-2) (2001) 110-115.

[56] J.F. Wallman, S.C. Donnellan. The utility of mitochondrial DNA sequences for the identification of forensically important blowflies (Diptera : Calliphoridae) in southeastern Australia. Forensic Sci. Int. 120 (1-2) (2001) 60-67.

[57] L.A. Nelson, J.F. Wallman, M. Dowton. Using COI barcodes to identify forensically and medically important blowflies. Med. Vet. Entomol. 21 (1) (2007) 44-52.

[58] O. Folmer, M. Black, W. Hoeh, R. Lutz, R. Vrijenhoek. DNA primers for amplification of mitochondrial cytochrome $\mathrm{c}$ oxidase subunit I from diverse metazoan invertebrates. Mol. Mar. Biol. Biotechnol. 3 (5) (1994) 294-299.

[59] J.D. Thompson, D.G. Higgins, T.J. Gibson. CLUSTAL W: improving the sensitivity of progressive multiple sequence alignment through sequence weighting, positionspecific gap penalties and weight matrix choice. Nucleic Acids Res. 22 (22) (1994) 46734680. 
[60] M. Kimura. A simple method for estimating evolutionary rates of base substitutions through comparative studies of nucleotide sequences. J. Mol. Evol. 16 (2) (1980) 111120.

[61] P.D. Hebert, A. Cywinska, S.L. Ball, J.R. deWaard. Biological identifications through DNA barcodes. Proc. Biol. Sci. 270 (1512) (2003) 313-321.

[62] J.H. McDonald. Handbook of Biological Statistics: Sparky House Publishing Baltimore; 2009.

[63] J.D. Wells, T. Pape, F.A.H. Sperling. DNA-based identification and molecular systematics of forensically important sarcophagidae (diptera). J. Forensic Sci. 46 (5) (2001) 1098-1102.

[64] M.L. Goff. A fly for the prosecution: how insect evidence helps solve crimes: Harvard University Press; 2000.

[65] K. Sukontason, P. Narongchai, C. Kanchai, K. Vichairat, P. Sribanditmongkol, T. Bhoopat, et al. Forensic entomology cases in Thailand: a review of cases from 2000 to 2006. Parasitol. Res. 101 (5) (2007) 1417-1423.

[66] R. Boonstra. Effect of the parasite Wohlfahrtia vigil on Microtus townsendii populations. Can. J. Zool. 55 (6) (1977) 1057-1060.

[67] K.L. Tabor, C.C. Brewster, R.D. Fell. Analysis of the successional patterns of insects on carrion in southwest Virginia. J. Med. Entomol. 41 (4) (2004) 785-795.

[68] R.A. Roberts. Myiasis in jack rabbits, Lepus californicus texianus. J. Parasitol. 18 (2) (1931) 102-104.

[69] W.B. Herms. An ecological and experimental study of Sarcophagidae with relation to lake beach debris. J. Exp. Zool. 4 (1) (1907) 45-83.

[70] I. Arnaldos, E. Romera, M.D. García, A. Luna. An initial study on the succession of sarcosaprophagous Diptera (Insecta) on carrion in the southeastern Iberian peninsula. Int. J. Legal Med. 114 (3) (2001) 156-162. 
[71] B. Greenberg, J.C. Kunich. Entomology and the law: Flies as forensic indicators. Cambridge, UK: Cambridge University Press; 2002.

[72] A. Gunn. Essential forensic biology. Oxford: Wiley; 2008.

[73] B. Eldridge, M. James. The typical muscid flies of California. Bull. Calif. Insect Survey. 6 (1957) 1-18.

[74] J.M. D'Almeida. Ovipositional substrates used by Calyptrate Diptera in Tijuca forest, Rio de Janeiro. Mem. Inst. Oswaldo Cruz. 89 (2) (1994) 261-264.

[75] V. Oliveira, J. d'Almeida, M. Paes, A. Sanavria. Population dynamics of Calyptrate Diptera (Muscidae and Sarcophagidae) at the RIO-ZOO Foundation, Rio de Janeiro, RJ, Brazil. Braz. J. Biol. 62 (2) (2002) 191-196.

[76] L. Siddons, D. Roy. On the life history of Synthesiomyia nudiseta van der Wulp (Diptera, Muscidae), a myiasis-producing fly. Parasitology. 34 (3-4) (1942) 239-245.

[77] Y. Velásquez, T. Ivorra, A. Grzywacz, A. Martínez-Sánchez, C. Magaña, A. GarcíaRojo, et al. Larval morphology, development and forensic importance of Synthesiomyia nudiseta (Diptera: Muscidae) in Europe: a rare species or just overlooked? Bull. Entomol. Res. 1 (1) (2012) 1-13.

[78] K. Jordaens, G. Sonet, R. Richet, E. Dupont, Y. Braet, S. Desmyter. Identification of forensically important Sarcophaga species (Diptera: Sarcophagidae) using the mitochondrial COI gene. Int. J. Legal Med. 127 (2) (2013) 491-504.

[79] M. Benecke, R. Lessig. Child neglect and forensic entomology. Forensic Sci. Int. 120 (1-2) (2001) 155-159.

[80] O.S. Morris, R.N. Titchener. Blowfly species composition in sheep myiasis in Scotland. Med. Vet. Entomol. 11 (3) (1997) 253-256.

[81] E.S. Wong, G.A. Dahlem, R.W. DeBry. Using DNA to better understand cryptic species complexes in the dung breeding Ravinia (Diptera: Sarcophagidae). Entomological Society of America Annual Meeting. Knoxville, TN2012. 
[82] T.L. Whitworth, R.D. Dawson, H. Magalon, E. Baudry. DNA barcoding cannot reliably identify species of the blowfly genus Protocalliphora (Diptera : Calliphoridae). Proc. Biol. Sci. 274 (1619) (2007) 1731-1739.

[83] V.J. Cervenka, R.D. Moon. Arthropods associated with fresh cattle dung pats in Minnesota. J. Kansas Entomol. Soc. 64 (2) (1991) 131-145. 